https://doi.org/10.15407/ufm.19.02.195

PACS numbers: 06.60.Vz, 61.80.Fe, 62.20.Qp, 68.37.Lp, 81.40.Pq, 81.40.Wx, 81.65.Lp, 82.80.Ej, 83.50.Uv

\author{
YU.F. IVANOV ${ }^{1,2}$, V.E. GROMOV ${ }^{3}$, S.V. KONOVALOV ${ }^{4}$, \\ D.V. ZAGULYAEV ${ }^{3}$, E.A. PETRIKOVA', and A.P. SEMIN ' \\ ${ }^{1}$ Institute of High-Current Electronics, SB RAS, \\ 2/3 Akademicheskiy Ave., 634055 Tomsk, Russia \\ 2 National Research Tomsk Polytechnic University, \\ 2/3 Akademicheskiy Ave., 634055 Tomsk, Russia \\ ${ }^{3}$ Siberian State Industrial University, \\ 42 Kirov Str., 654007 Novokuznetsk, Russia \\ ${ }^{4}$ Academician S. P. Korolev Samara National Research University, \\ 34 Moskovskoye Shosse, 443086 Samara, Russia

\section{MODIFICATION OF STRUCTURE AND SURFACE PROPERTIES OF HYPOEUTECTIC SILUMIN BY INTENSE PULSE ELECTRON BEAMS}

Methods of contemporary physical materials science are applied for the analysis of structural and phase states, tribological and mechanical properties of hypoeutectic silumin treated by electron beams with parameters as follow: energy density $10-35 \mathrm{~J} / \mathrm{cm}^{2}$, pulse duration $-10 \mu \mathrm{s}$, number of pulses -3 , pulse-repetition frequency $-0.3 \mathrm{~Hz}$. The initial structure of silumin comprises grains of aluminiumbased solid solution, eutectic grains, inclusions of silicon and intermetallic compounds with different shapes and sizes. Electron beam treatment (EBT) with energy density of $20-35 \mathrm{~J} / \mathrm{cm}^{2}$ causes melting of the surface layer, dissolution of silicon inclusions and intermetallic compounds. A structure of high-speed cellular crystallization is formed, and submicro- and nanosize particles of the second phase are reprecipitated. An average size of crystallization cells are of $0.3-0.5 \mu \mathrm{m}$ at the irradiated surface and of $0.4-0.8 \mu \mathrm{m}$ on the lower edge of the layer with the cellular structure. The graded structure and phase states are analysed at a depth of up to $120 \mu \mathrm{m}$. The submicron grains of lamellar eutectic are detected at a depth of $15 \mu \mathrm{m}$. The lateral sizes of eutectic lamellae are within the range of $25-50 \mathrm{~nm}$. The study indicates that nanohardness of irradiated silumin changes nonmonotonously and reaches its maximum at a depth of about $30 \mu \mathrm{m}$, which is approximately four times higher than hardness in the initial state. Hardness of the layer close to the irradiated surface (that is at a depth of $\approx 5 \mu \mathrm{m}$ ) is higher by a factor of $\approx 1.6$ than that of 
as-cast silumin. The paper provides physical interpretation of the changes occurring in structure and properties during irradiation.

Keywords: hypoeutectic silumin, electron beams, cells of high-speed crystallization, eutectic, intermetallic compounds, nanohardness.

\section{Introduction}

Currently, silumin is widely applied for manufacturing of multipurpose components, ranging from household appliances to devices used in car and aircraft engineering, mainly due to their low cost, high casting properties, corrosion and wear resistance, and a low coefficient of thermal expansion. However, particles of silicon in silumin eutectic and inclusions of intermetallic compounds have a rough lamellar or needleshaped form in foundry goods manufactured without special processing of a melt, deteriorating, therefore, strength and plastic properties of material and manufactured items [1-5]. Modification of the melt makes it possible to change form and sizes of silicon crystals and intermetallic compounds [6-9]. Beryllium, vanadium, tungsten, niobium, cobalt and some other materials are recommended for applying as modifiers [1-9]. The use of these modifiers has some shortcomings, such as high toxicity of components as well as their deficit and high cost of a finite product, consequently.

Recent years, concentrated flows of energy (strong ion and intense pulse electron beams, plasma fluxes, laser rays) are used as an instrument for significant transformation of element and phase composition, structure and properties of the material surface [10-12]. Ultra-high speeds of heating and cooling of the surface layer allow formation of a homogenous submicro- and nanosize structure, which improves general characteristics of devices [13-15].

Electron-beam treatment possesses a number of advantages in comparison with other methods using concentrated energy flows. It is outlined in studies of Chinese researchers [16-26] that processing of eutectic and hypereutectic silumin by electron beams (pulse duration only some microseconds) (electron beam unit 'Nadezhda-2') results in essential modification of properties in the material surface under the influence of dynamic stress fields generated at heating, melting, and cooling. This modification is associated with considerable refining of the structure, improvement of wear and corrosion resistance, as well as increase of hardness.

It is highlighted [16] that an equiaxial fine-grained structure (with thickness of some micrometers) is formed on the surface in the melted layer due to electron beam treatment (density of beam energy $-3 \mathrm{~J} / \mathrm{cm}^{2}$, duration $-1 \mu \mathrm{s}$, number of pulses -10 ) of eutectic alloy $\mathrm{Al}-12.6 \mathrm{Si}$. Under the surface, there is a remelted layer (with thickness of $\approx 10 \mu \mathrm{m}$ ) 
detected containing oversaturated $\mathrm{Al}$ solid solution. A significant rise of wear resistance (with factor of 2.5) is reported as a result of electron beam treatment, which is possible due to hardening of the fine-grained structure and solid solution [16]. Electron beam treatment $\left(3 \mathrm{~J} / \mathrm{cm}^{2}\right.$, $1 \mu \mathrm{s}, 15$ pulses $)$ of hypereutectic silumin $(17.5 \% \mathrm{Si})$ is related to significant improvement of the structure in the alloy with big silicon inclusions [17]. No new phases are generated after electron beam treatment, although all diffraction peaks are widened as compared with the initial state, and diffraction peaks of aluminium are shifted to bigger angles. Furthermore, after electron beam treatment there are small structures detected in the alloy containing coarse inclusions of silicon in the initial state. These structures are possible due to mutual diffusion of silicon and aluminium, resulting, in its turn, in solid solution of aluminium and silicon. Chemical compositions of silicon and aluminium are gradually distributed, forming 'halo' morphology on the structural images. The gradient nature of the irradiated region is also corroboration that microhardness of silicon is distributed from the centre towards the edge 'halo' [18]. The researchers [18] also revealed a new phase in the same alloy because of electron beam treatment, and a significant decline of aluminium lattice parameter after 15 pulses. Microhardness of silicon varies non-monotonously from the centre to edges of the zone with diffusion of aluminium and silicon; microhardness in the centre of silicon plates gradually decreases together with the growing number of pulses. At the beginning, wear resistance increases, dropping afterwards with the growing number of pulses, here wear losses lower to $84.6 \%$ after 15 pulses [17]. Reference [19] focuses on the influence of pulse number in electron beam treatment (energy density of electron beam $2.5 \mathrm{~J} / \mathrm{cm}^{2}$ ) of silumin $(15 \% \mathrm{Si})$ on the structure and phase composition in the 'halo' zone. It is demonstrated that this treatment furthers melting of the surface layer (thickness of up to $10 \mu \mathrm{m}$ ). As for hypereutectic alloy $\mathrm{Al}-20 \% \mathrm{Si}$, it is found [20] that initial particles of silicon dissolve in aluminium matrix and oversaturated solid solution is formed in the melted layer because of electron beam treatment. The researchers suggest this phenomenon is caused by silicon diffusion. The data of x-ray structural analysis point out at a decline of aluminium lattice parameter and increasing micro-deformation of the alloy crystal lattice after electron beam treatment. The assessment of silicon microhardness revealed a gradient change from the centre towards edges of the zone processed by electron beams $[21,22]$.

It is reported in Ref. [24] that microstructure and mechanical properties of $\mathrm{Al}-\mathrm{Si}-\mathrm{Pb}$ alloy improve significantly when irradiating the surface of samples in conditions of electron beam treatment $\left(1.5-2.5 \mathrm{~J} / \mathrm{cm}^{2}\right.$, $1.5 \mu \mathrm{s}, 15$ pulses). A considerable growth of wear resistance is indicated for alloy processed by electron beams (electron energy density of $2.0 \mathrm{~J} / \mathrm{cm}^{2}$ 
and $2.5 \mathrm{~J} / \mathrm{cm}^{2}$ ). Applying optical metallographic methods and photoelectron $\mathrm{x}$-ray spectroscopy it is found out that low speed of wear and friction coefficient under high loads are caused by a lubricating film, which covers the tested surface. The film contains atoms of iron, aluminium, silicon and lead, which are components of compound $\mathrm{Pb}_{4} \mathrm{SiO}_{6}$. The growth of applied load causes oxidation wear, destruction of a film and adhesion wear [24]. Similar results were obtained for $\mathrm{Al}-\mathrm{Pb}$ alloy processed by electron beams [25]. These include significant improvement of wear resistance and mechanical properties. The scientists suggest that it is related to the lubricating film. The type of wear varies from the oxidation one at low loads to adhesion one at high loads.

It is reported on formation of craters and microcraters on the melted surface and heightened number of vacancies and dislocations in pure aluminium irradiated by electron beams (with energy density of $3 \mathrm{~J} / \mathrm{cm}^{2}$ ). The data on distribution of microhardness demonstrate that the modified layer is some hundreds of micrometers, exceeding considerably the zone of thermal impact. Electron beam treatment of $\mathrm{Fe}-40 \% \mathrm{Al}$ alloy in the heat mode (without melting the surface) results in formation of a fine-grained structure and modification of the surface texture. Alongside with formation of vacancies, it furthers significant growth of the surface microhardness. Corrosion resistance of the alloys remains the same [26].

Therefore, a number of studies examined the influence of concentrated flows of energy on mechanical properties of metals and alloys, including silumin. Some research provided information on the influence of laser, plasma, electron beam processing on tribological and mechanical properties, formation of the structure and phase composition in aluminium alloys, including silumin. The data of research suggest that processing by a pulse electron beam is a promising and established procedure to modify structure and phase states in the surface layers of metals and alloys.

The goal of this work lies in analysis of the structure and properties of hypoeutectic silumin irradiated by pulse electron beam with submillisecond exposure time and density of electron beam varying in a wide range.

\section{Material and Research Methods}

The as-cast AK10M2H silumin was used as an investigated material. According to Russian Standard GOST 30620-98, this aluminium-based alloy contained $\mathrm{Si}(9.5-10.5$ wt.\%), $\mathrm{Cu}(2.0-2.5$ wt.\%), Ni (0.81.2 wt. \%), $\mathrm{Mg}(0.9-1.2$ wt.\%), Fe (up to 0.6 wt.\%), Mn (up to 0.05 wt. $\%$ ), Ti (up to 0.05 wt. $\%$ ), $\mathrm{Pb}$ (up to 0.05 wt. $\%$ ), Zn (up to 0.06 wt. $\%$ ), and Sn (up to 0.01 wt. $\%$ ). The samples were in the form of $20 \times 20 \times 10 \mathrm{~mm}$ plates. The surface of plates was irradiated by pulse electron beam, using the unit 'SOLO' [27] and according to the parameters 
as follow: energy of accelerated electrons $-17 \mathrm{keV}$, densities of electron beam energy $-10,15,20,25,30$, and $35 \mathrm{~J} / \mathrm{cm}^{2}$, pulse duration of electron beam $-150 \mu \mathrm{s}$, number of pulses -3 , pulse repetition frequency $-0.3 \mathrm{~s}^{-1}$. The structure of samples was examined using different types of microscopy: optical (metallographic microvisor $\mu$ Vizo-MET221), scanning (Philips SEM-515 with a microanalyser EDAX ECON IV) and transmission (JEM-2100F, JEOL) electron microscopy, x-ray structural analysis (diffractometer XRD 6000). The element composition of silumin was examined according to x-ray microspectral methods. Tribological tests were carried out using tribometer Pin on Disc and Oscillating TRIBOtester (TRIBOtechnic, France) at the following parameters: a ball of $\amalg X 15$ steel, diameter $-6 \mathrm{~mm}$, radius of track $-2 \mathrm{~mm}$, load -1 $\mathrm{N}$, distance $-5-80 \mathrm{~m}$. Hardness of the surface layer was measured with microhardness measuring device PMT-3 at a loaded indenter.

\section{Results and Discussions}

In the initial state, the structure of silumin contains grains of aluminium-based solid solution, eutectic grains, inclusions of silicon and intermetallic compounds of different sizes and forms varying in the wide ranges (Fig. 1).

Methods of x-ray microspectral analysis were used to define element composition in the inclusions. Figure 2 shows one of the variant to analyse the element composition of as-cast silumin. The numerical data of obtained results are given in Table 1.

The analysis of data, given in Fig. 2, $a$ and $b$, indicates that element composition in the thin section of silumin is similar to the element composition of AK10M2H silumin (Russian Standard GOST 30620-98). The element composition of inclusions (shown in Fig. 2, $c$, and given in Table 1) indicates that alloying elements are distributed nonuniformly in as-cast silumin. The main part of silumin (zone 1, Fig. 2,c) is alu-

Table 1. The x-ray microspectral analysis results for a thin section represented with electron-microscopy image in Fig. 2

\begin{tabular}{|l|r|r|r|r|r|r|r|r|}
\hline \multirow{2}{*}{ Element } & \multicolumn{7}{|c|}{ Number of analysed part } \\
\cline { 2 - 10 } & \multicolumn{2}{|c|}{1} & \multicolumn{2}{|c|}{2} & \multicolumn{2}{|c|}{3} & \multicolumn{2}{|c|}{4} \\
\cline { 2 - 10 } & \multicolumn{1}{|c|}{ wt.\% } & at.\% & \multicolumn{1}{|c|}{ wt.\% } & at.\% & wt.\% & at.\% & wt.\% & at.\% \\
\hline $\mathrm{Mg}\left(K_{\alpha}\right)$ & 0.97 & 1.09 & 22.71 & 25.35 & 1.67 & 2.26 & 0.51 & 0.68 \\
$\mathrm{Al}\left(K_{\alpha}\right)$ & 94.97 & 96.26 & 47.87 & 48.15 & 62.87 & 76.82 & 68.81 & 82.07 \\
$\mathrm{Si}\left(K_{\alpha}\right)$ & 1.60 & 1.56 & 25.79 & 24.93 & 3.76 & 4.41 & 0.73 & 0.84 \\
$\mathrm{Fe}\left(K_{\alpha}\right)$ & 0.33 & 0.16 & 0.25 & 0.12 & 0.50 & 0.29 & 4.39 & 2.53 \\
$\mathrm{Ni}\left(K_{\alpha}\right)$ & 0.43 & 0.20 & 0.25 & 0.11 & 0.56 & 0.32 & 22.56 & 12.37 \\
$\mathrm{Cu}\left(K_{\alpha}\right)$ & 1.70 & 0.73 & 3.13 & 1.34 & 30.65 & 15.9 & 3.00 & 1.52 \\
\hline
\end{tabular}



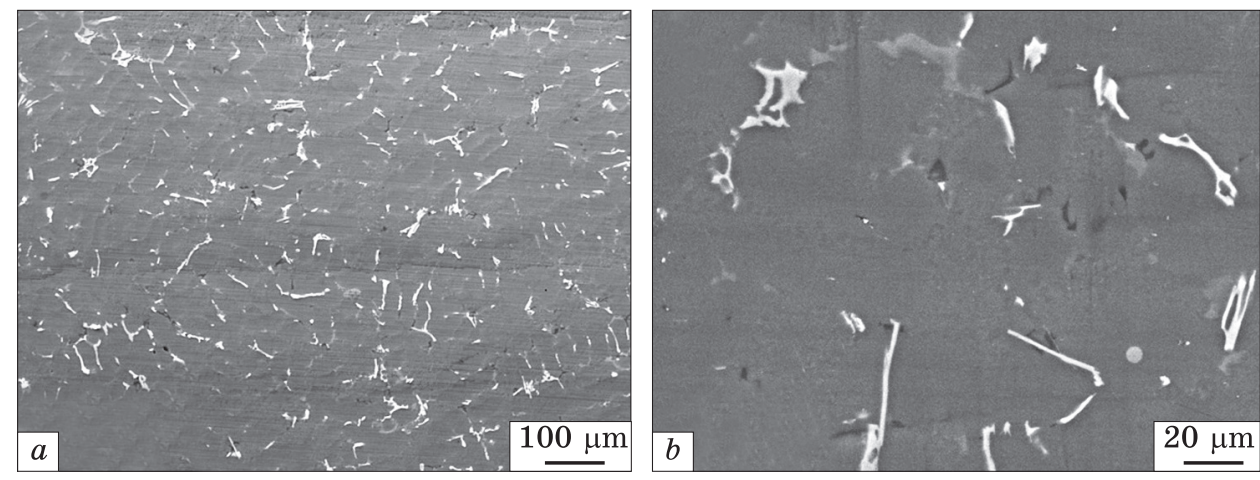

Fig. 1. Electron-microscopy image of the as-cast silumin structure
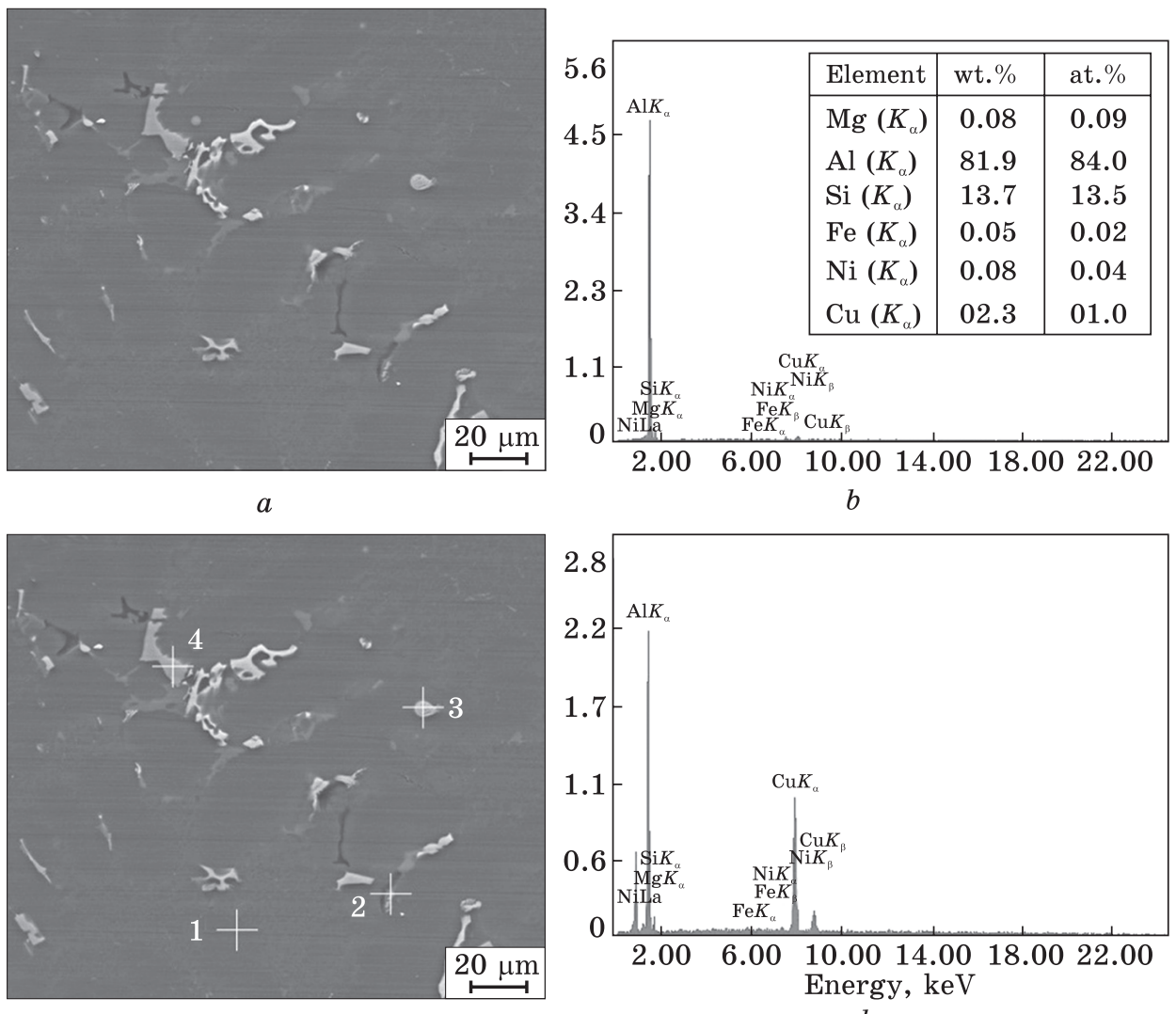

$c$

$d$

Fig. 2. Electron-microscopy image of as-cast silumin $(a, c)$ and energy spectra $(b, d)$ obtained on the surface zone shown in $(a, c)$. An inclusion is designated with the number 3 . Table in $(b)$ gives numerical results of the analysed element composition in the zone $(a)$ 

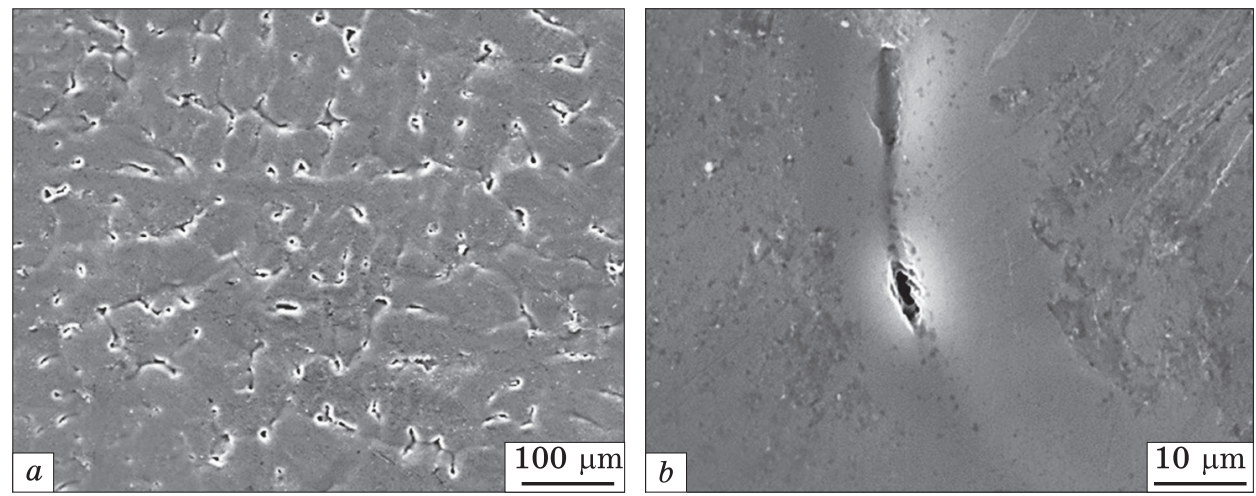

Fig. 3. Electron-microscopy image of silumin surface structure irradiated by electron beam (electron-beam energy density $E_{s}=10 \mathrm{~J} / \mathrm{cm}^{2}$ )
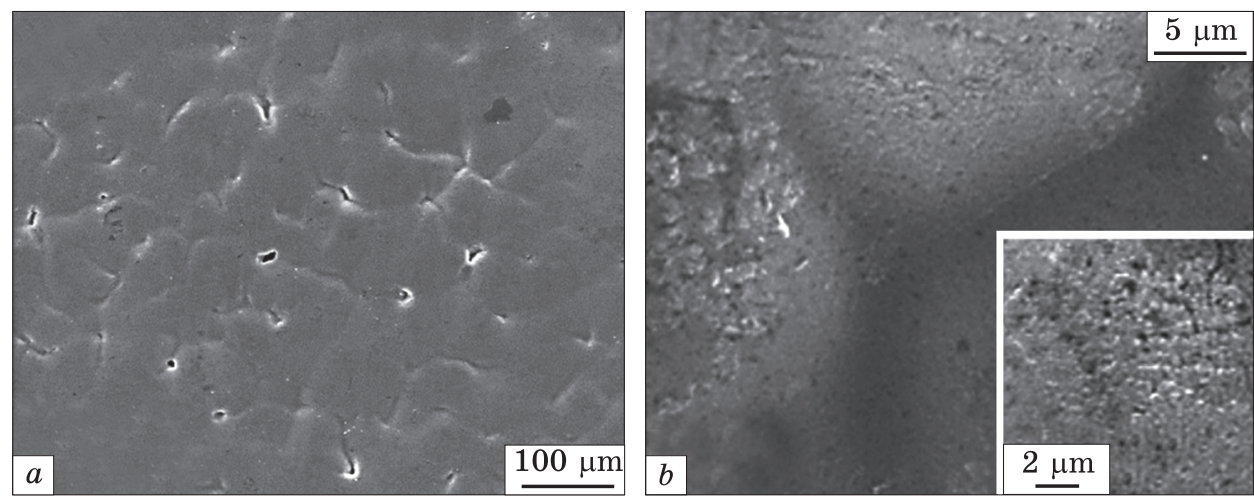

Fig. 4. Electron-microscopy image of the surface structure of silumin after by electron beam irradiation (electron-beam energy density $E_{s}=15 \mathrm{~J} / \mathrm{cm}^{2}$ )

minium-based solid solution, in which the amount of alloying elements is far below the average (Fig. 2, $b$, Table 1). Inclusions designated with numbers 2, 3, and 4 in Fig. 2, $c$ are saturated with magnesium, silicon and copper (inclusion 2), copper and magnesium (inclusion 3), nickel, iron and copper (inclusion 4). These results, revealing nonuniform distribution of alloying elements in as-cast silumin, are similar to those obtained when examining other inclusions.

Therefore, the data of SEM and x-ray microspectral studies demonstrate that alloying elements distribute nonuniformly in as-cast AK10M2H silumin.

The surface layer in silumin was homogenized, irradiating the surface by intense pulse electron beam. It is established that irradiation of silumin by electron beam (density of energy $E_{s}=10 \mathrm{~J} / \mathrm{cm}^{2}$ ) is associated with melting of aluminium along the interface with inclusions of the 

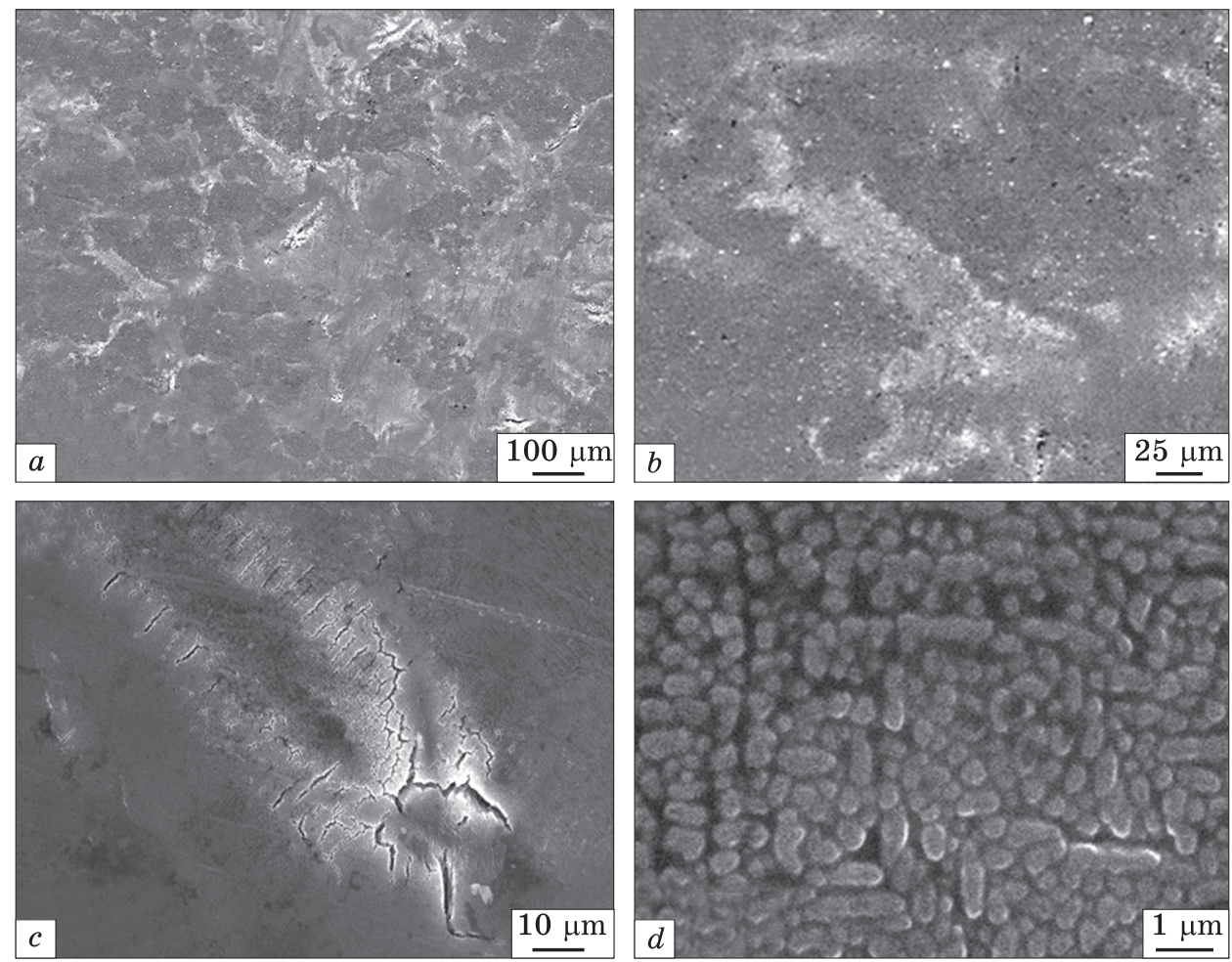

Fig. 5. Electron-microscopic image of the surface structure in silumin treated with electron beam (electron-beam energy density $E_{s}=20 \mathrm{~J} / \mathrm{cm}^{2}$ )

second phase (Fig. 3). The width of the melted layer (in the irradiation plane) is of $10-15 \mu \mathrm{m}$ (Fig. $3, b$ ).

Selective melting in the surface of silumin is caused by a low thermal conductivity coefficient of inclusions. Consequently, the adjacent layer of aluminium is melted under pulse irradiation of samples. No melting material is observed in the regions without inclusions: scratches made during mechanical polishing of the material (Fig. $3, b$ ) indicate this fact.

The increase in energy density of electron beam up to $15 \mathrm{~J} / \mathrm{cm}^{2}$ is related to disappearance of scratches on the surface of aluminium, indicating this way, melting of the surface layer in aluminium (Fig. 4, a). Melting of aluminium adjacent to inclusions of the second phase is associated with formation of a structure with cellular crystallization. Cells vary from $200 \mathrm{~nm}$ to $220 \mathrm{~nm}$ (Fig. 4, $b$ ). The width of layers with the structure of cellular crystallization reaches 15-20 $\mu \mathrm{m}$. Cells cannot be found far from inclusions of the second phase, which can indicate on a small thickness of the melted surface layer. 
At the energy density of electron beam of $20 \mathrm{~J} / \mathrm{cm}^{2}$ and above, the inclusions of silicon and intermetallic compounds in the surface layer are dissolved dynamically (Fig. 5). In conditions of ultra-fast cooling in the melted layer, inclusions of intermetallic compounds dissolve and (at the same time) a net of microcracks appears on the surface, which might be an evidence of a high level of tension stresses and heighten brittleness of the material (Fig. 5, c). Melting and high-speed cooling of the surface layer in silumin are reasons for formation of the structure with cellular crystallization (Fig. 5, $d$ ). The sizes of cells vary within the range of $400-500 \mathrm{~nm}$, increasing slightly when energy density of electron beam changes within the range of $20-35 \mathrm{~J} / \mathrm{cm}^{2}$.

In electron-microscopy images of silumin irradiated by electron beam there are zones detected with significantly different contrast (Fig. 5, $a-c$ ). This fact indicates, probably, that alloying elements are distributed nonuniformly in the surface layer of the material. Actually, applying methods of x-ray microspectral analysis it was found out that element composition of the surface layer in silumin irradiated by intense pulse electron beam is related to the selected zone of analysis (Table 2; regions of analysis are designated with numbers).

Table 3 provides the results of element analysis carried out in the surface layer of silumin irradiated by electrons with various energy density of electron beam $\left(25-35 \mathrm{~J} / \mathrm{cm}^{2}\right)$. Obtained results were averaged over six regions: each with the area of $1.16 \mathrm{~mm}^{2}$. Analysing the data in

Table 2. Concentration distribution of alloying elements in the surface layer of silumin irradiated by electron beam ( $25 \mathrm{~J} / \mathrm{cm}^{2}, 150 \mu \mathrm{s}, 3$ pulses), at.\%

\begin{tabular}{|l|c|c|c|c|c|c|c|c|c|}
\hline Element & 1 & 2 & 3 & 4 & 5 & 6 & 7 & 8 & 9 \\
\hline $\mathrm{Mg}\left(K_{\alpha}\right)$ & 1.0 & 1.7 & 1.9 & 1.8 & 1.3 & 1.5 & 1.5 & 1.6 & 1.7 \\
$\mathrm{Si}\left(K_{\alpha}\right)$ & 7.0 & 10 & 7.6 & 3.9 & 6.2 & 4.4 & 6.2 & 7.5 & 4.5 \\
$\mathrm{Ni}\left(K_{\alpha}\right)$ & 0.5 & 0.8 & 0.6 & 0.8 & 0.4 & 0.4 & 0.6 & 0.4 & 0.6 \\
$\mathrm{Cu}\left(K_{\alpha}\right)$ & 1.3 & 1.2 & 1.2 & 1.1 & 1.1 & 0.9 & 0.9 & 1.0 & 1.0 \\
\hline
\end{tabular}

Table 3. The concentration of alloying elements in the surface layer of silumin irradiated by electron beam. X-ray microspectral analysis

\begin{tabular}{|c|c|c|c|c|c|c|c|c|c|}
\hline \multirow{3}{*}{ Element } & \multicolumn{6}{|c|}{ Energy density of electron beam, $\mathrm{J} / \mathrm{cm}^{2}$} & \multirow{3}{*}{$\begin{array}{c}\begin{array}{c}\text { In } \\
\text { a surface } \\
\text { layer }\end{array} \\
\text { wt. } \%\end{array}$} & \multirow{3}{*}{$\begin{array}{c}\begin{array}{c}\text { In } \\
\text { a bulk }\end{array} \\
\text { wt. } \%\end{array}$} & \multirow{3}{*}{$\begin{array}{c}\text { GOST state } \\
\text { standard }\end{array}$} \\
\hline & \multicolumn{2}{|c|}{25} & \multicolumn{2}{|c|}{30} & \multicolumn{2}{|c|}{35} & & & \\
\hline & wt. $\%$ & at. $\%$ & wt. $\%$ & at. $\%$ & wt. $\%$ & at. $\%$ & & & \\
\hline $\operatorname{Mg}\left(K_{\alpha}\right)$ & 1.34 & 1.52 & 1.33 & 1.51 & 1.29 & 1.45 & 1.32 & 1.17 & $0.9-1.2$ \\
\hline $\operatorname{Si}\left(K_{\alpha}\right)$ & 5.55 & 5.43 & 5.94 & 5.81 & 5.5 & 5.36 & 5.66 & 10.4 & $9.5-10.5$ \\
\hline $\mathrm{Ni}\left(K_{\alpha}\right)$ & 1.01 & 0.47 & 1.22 & 0.56 & 0.8 & 0.37 & 1.01 & 1.25 & $0.8-1.2$ \\
\hline $\mathrm{Cu}\left(K_{\alpha}\right)$ & 2.46 & 1.07 & 2.49 & 1.07 & 2.5 & 1.07 & 2.48 & 2.89 & $2.0-2.5$ \\
\hline
\end{tabular}




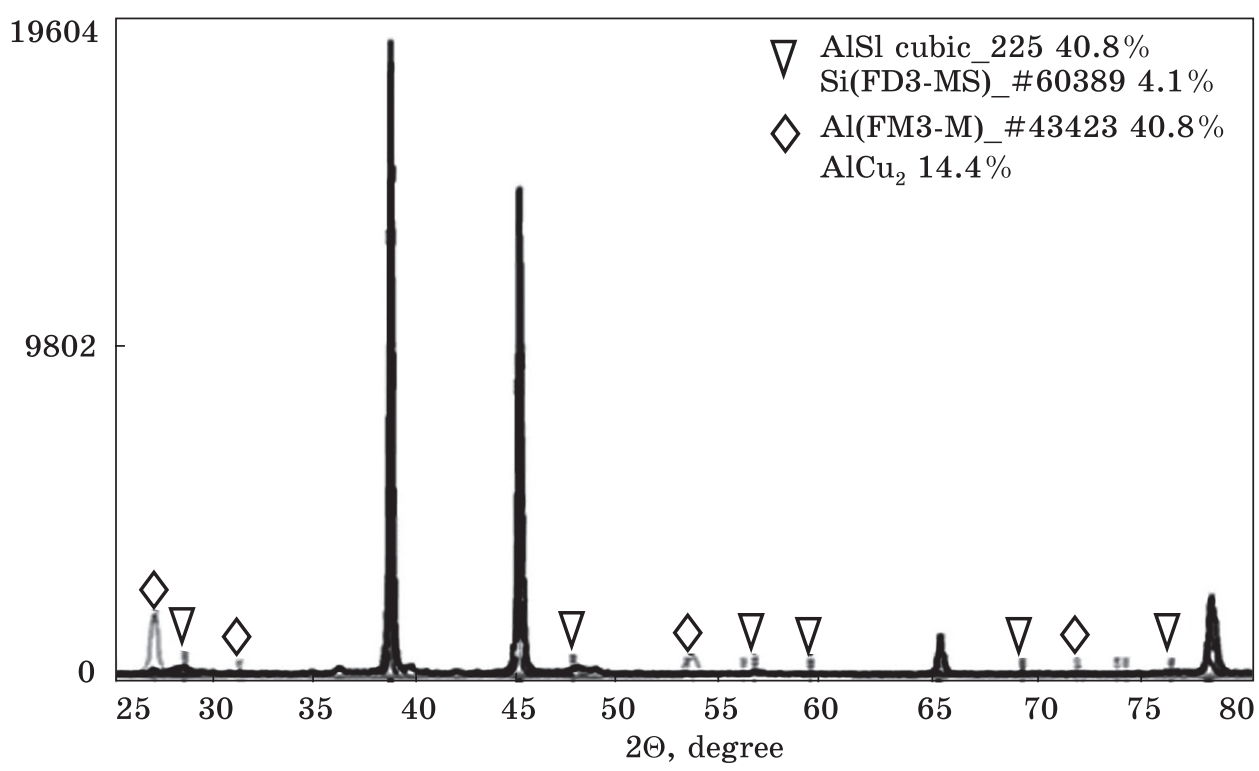

Fig. 6. The section of x-ray image for silumin irradiated by intense pulse electron beam $\left(35 \mathrm{~J} / \mathrm{cm}^{2}, 150 \mu \mathrm{s}, 3\right.$ pulses $)$

Table 3, we can conclude that averaging of results according to large areas reveals only insignificant (within the limits of measurement error) changes in the concentration of alloying elements in the surface layer of irradiated samples, excluding silicon. The concentration of silicon in the surface layer is almost twice lower than that in the main part of the sample.

Therefore, irradiation of silumin by pulse electron beam $\left(20-35 \mathrm{~J} / \mathrm{cm}^{2}\right.$, $150 \mu \mathrm{s}, 3$ pulses) is associated with dissolution of silicon and intermetallic compounds in the surface layer. It is hardly possible to synthesize a surface layer with uniform distribution of alloying elements. However, element composition in the surface layer of silumin irradiated by electron beam varies less significantly than that in the initial material. A substantial drop of silicon concentration in the surface layer of silumin indicates, probably, a graded element composition in the material, forming under irradiation by pulse electron beam.

To determine phase composition and state of the crystal lattice in the surface layer of silumin modified by intense pulse electron beam methods of x-ray microstructural analysis were applied. Figure 6 shows a section of $\mathrm{x}$-ray picture taken on the sample irradiated by electron beam (35 J/ $\mathrm{cm}^{2}, 150 \mu \mathrm{s}, 3$ pulses). The data of numerical x-ray structural analysis are represented in Table 4 . Taking into consideration these data (in Table 4), it can be stated that high-speed crystallization and subsequent cooling initiated by irradiation of silumin by intense pulse elec- 
tron beam is related to formation of a multiphase surface layer, which contains aluminium-based solid solutions designated AlSi and $\mathrm{Al}$ in Table 4, silicon and copper aluminide $\mathrm{AlCu}_{2}$. Apparently, the synthesis of two aluminium-based solid solutions is most detectable at a density of electron beam of $35 \mathrm{~J} / \mathrm{cm}^{2}$. The crystal lattice parameter in AlSi solid solution is lower than that of pure aluminium $(0.40494 \mathrm{~nm})$ [28]. This solid solution can be synthesized due to alloying of aluminium with silicon, copper, iron, and nickel atoms, since their atom radii $\left(R_{\mathrm{Si}}=0.132 \mathrm{~nm}, R_{\mathrm{Cu}}=0.128 \mathrm{~nm}, R_{\mathrm{Fe}}=0.126 \mathrm{~nm}, R_{\mathrm{Ni}}=0.124 \mathrm{~nm}\right)$ are smaller than the aluminium-atom radius $\left(R_{\mathrm{Al}}=0.143 \mathrm{~nm}\right)$ [28]. Therefore, substitution of aluminium atoms causes the decrease of crystal lattice parameter in AlSi solid solution.

If energy density of electron beam is $35 \mathrm{~J} / \mathrm{cm}^{2}$, the parameter of the crystal lattice in the second phase of aluminium-based solid solution (designated $\mathrm{Al}$ in Table 4) is higher than that of pure aluminium. It can be related to dissolution of particles of magnesium containing intermetallic compounds, and saturation of aluminium solid solution with atoms of magnesium $\left(R_{\mathrm{Mg}}=0.160 \mathrm{~nm}\right)$ [28]. The parameter of silicon crystal lattice is lower than that in the Ref. [28], where $a_{\mathrm{Si}}=0.54307$ $\mathrm{nm}$. It indicates that silicon-based solid solution is synthesized in the process of crystallization, and it contains atoms of copper, nickel and iron, since atom radii of these elements are smaller than the atom radius of silicon. The relative concentration of silicon in the modified layer of silumin is rather low and similar to that obtained by methods of x-ray microspectral analysis (Table 1).

Thus, the data obtained by methods of $\mathrm{x}$-ray microspectral analysis (SEM) and x-ray structural analysis make it possible to state that irradiation of silumin by intense pulse electron beam in the mode of melting

Table 4. The data of $\mathrm{x}$-ray structural analysis of silumin irradiated by pulse electron beam for two irradiation regimes: $1\left(25 \mathrm{~J} / \mathrm{cm}^{2}, 150 \mu \mathrm{s}, 3\right.$ pulses $)$ and $2\left(35 \mathrm{~J} / \mathrm{cm}^{2}, 150 \mu \mathrm{s}, 3\right.$ pulses $)$

\begin{tabular}{|c|c|c|c|c|}
\hline \multirow{2}{*}{$\begin{array}{c}\text { Irradiation } \\
\text { regime }\end{array}$} & \multirow{2}{*}{$\begin{array}{c}\text { Phase } \\
\text { composition }\end{array}$} & $\begin{array}{c}\text { Relative } \\
\text { concentration, } \%\end{array}$ & \multicolumn{2}{|c|}{ Lattice parameter, $\mathrm{nm}$} \\
\cline { 3 - 5 } 1 & $\mathrm{AlSi}$ & 53.1 & 0.40412 & \\
\hline 2 & & 40.8 & 0.40435 & \\
1 & $\mathrm{Al}$ & 38.3 & 0.40419 & \\
2 & & 40.7 & 0.40508 & \\
1 & $\mathrm{Si}$ & 8.6 & 0.54191 & \\
2 & & 4.1 & 0.54274 & \\
1 & $\mathrm{AlCu}$ & 0.0 & 0.40626 & 0.57950 \\
2 & & 14.4 & 0.40311 & 0.57492 \\
\hline
\end{tabular}



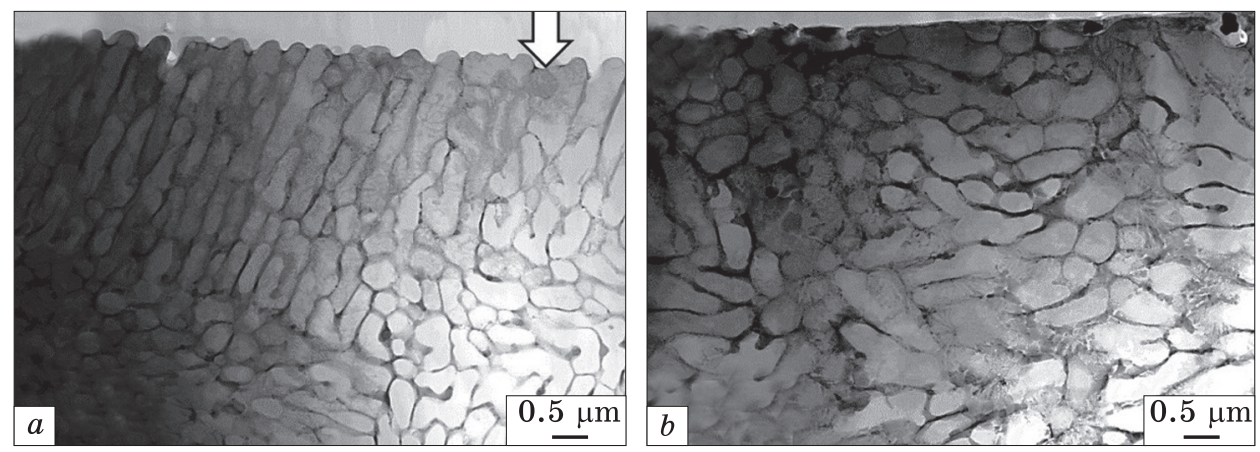

Fig. 7. The structure of the surface layer in silumin treated by electron beams with different electron-beam energy density: $25 \mathrm{~J} / \mathrm{cm}^{2}(a)$ and $35 \mathrm{~J} / \mathrm{cm}^{2}(b)$
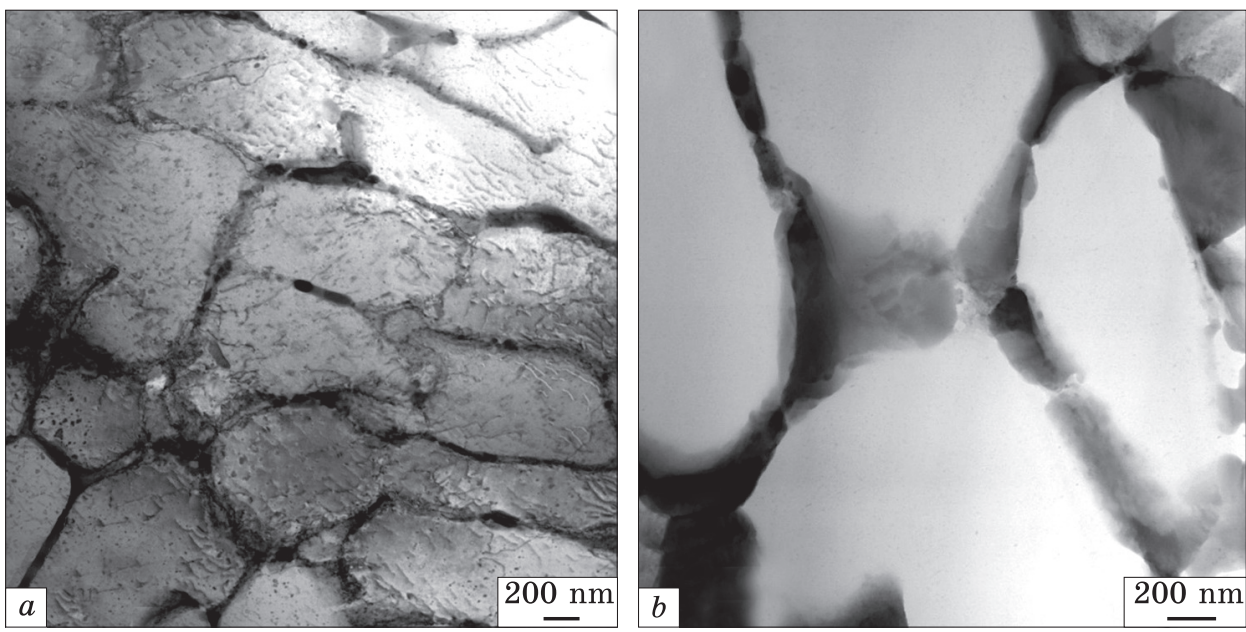

Fig. 8. The structure of cellular crystallization in the surface layer of silumin treated by electron beam with different energy density: $25 \mathrm{~J} / \mathrm{cm}^{2}(a)$ and $35 \mathrm{~J} / \mathrm{cm}^{2}(b)$

doesn't result in homogenization of the surface layer. Further highspeed crystallization is associated with formation of two aluminiumbased solid solutions, differently saturated by atoms of silicon and other alloying and impurity elements.

Using methods of TEM, thin foils' studies on the defect substructure of the surface layer in silumin, irradiated by electron beam were carried out, and as revealed (Fig. 7), the irradiation of silumin by intense pulse electron beam causes formation of a cellular structure in the surface layer at the stage of high-speed crystallization. Sizes of cells vary from $0.3 \mu \mathrm{m}$ to $0.5 \mu \mathrm{m}$ and increase simultaneously with the growth of energy density of electron beam. The cells are separated by thin layers of the second phase; sizes of the layers do not exceed $100 \mathrm{~nm}$ (Fig. 8). 

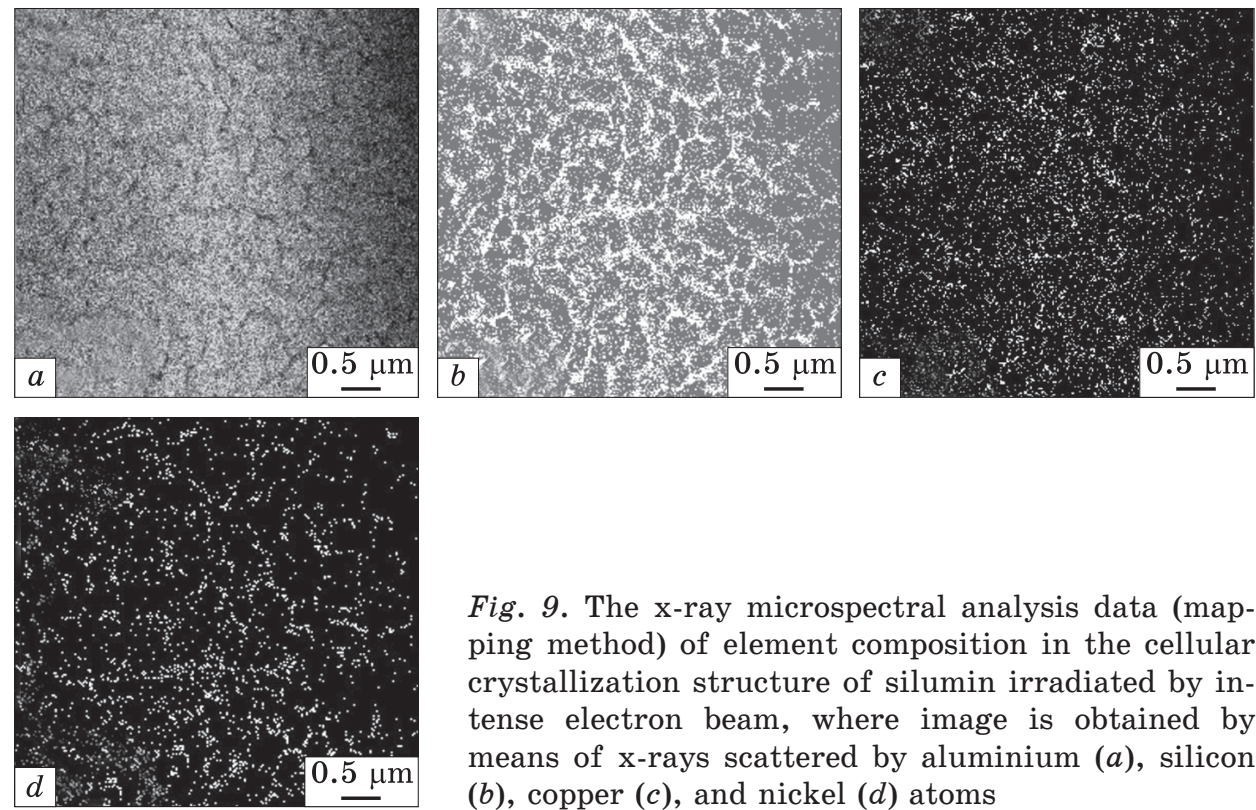

Fig. 9. The x-ray microspectral analysis data (mapping method) of element composition in the cellular crystallization structure of silumin irradiated by intense electron beam, where image is obtained by means of x-rays scattered by aluminium $(a)$, silicon $(b)$, copper $(c)$, and nickel $(d)$ atoms

Throughout the cells, there is dislocation structure detected in form of chaotically distributed dislocations (Fig. 8, $a$ ).

According to the data of x-ray microspectral analysis of element composition in thin foils (mapping method), given in Fig. 9, the cells are formed by aluminium-based solid solution (Fig. 9, $a$ ). Layers separating cells of crystallization are saturated with atoms of silicon, copper and nickel (Fig. 9, $b-d$ ).

Therefore, results of x-ray microspectral analysis (SEM and TEM) and x-ray structural analysis show that irradiation of silumin by intense pulse electron beam in the mode of melting and subsequent high-speed crystallization are associated with formation of a multiphase submicro-

Table 5. The conditions of tribological tests of silumin samples

\begin{tabular}{|l|l|l|l|}
\hline \multicolumn{2}{|c|}{ Triboparameters } & \multicolumn{2}{c|}{ Material static friction partner } \\
\hline Normal load & 1.0 & Substrate & Steel 100 Cr6 \\
Sliding speed & $25.0 \mathrm{~mm} / \mathrm{s}$ & Coating & No \\
Sliding length & $20.0 \mathrm{~m}$ & Supplier & No \\
Wear track radius & $2.0 \mathrm{~mm}$ & Cleaning & No \\
& & Dimension & $6000 \mu \mathrm{m}$ \\
Temperature & $23.0{ }^{\circ} \mathrm{C}$ & Geometry & Ball \\
Humidity & $50.0 \% \mathrm{r} . \mathrm{H}$. & Young modulus & $205000 \mathrm{MPa}$ \\
Atmosphere & Air & Poisson's ratio & 0.00 \\
Friction threshold & Not used (standard $f=1)$ & & \\
\hline
\end{tabular}



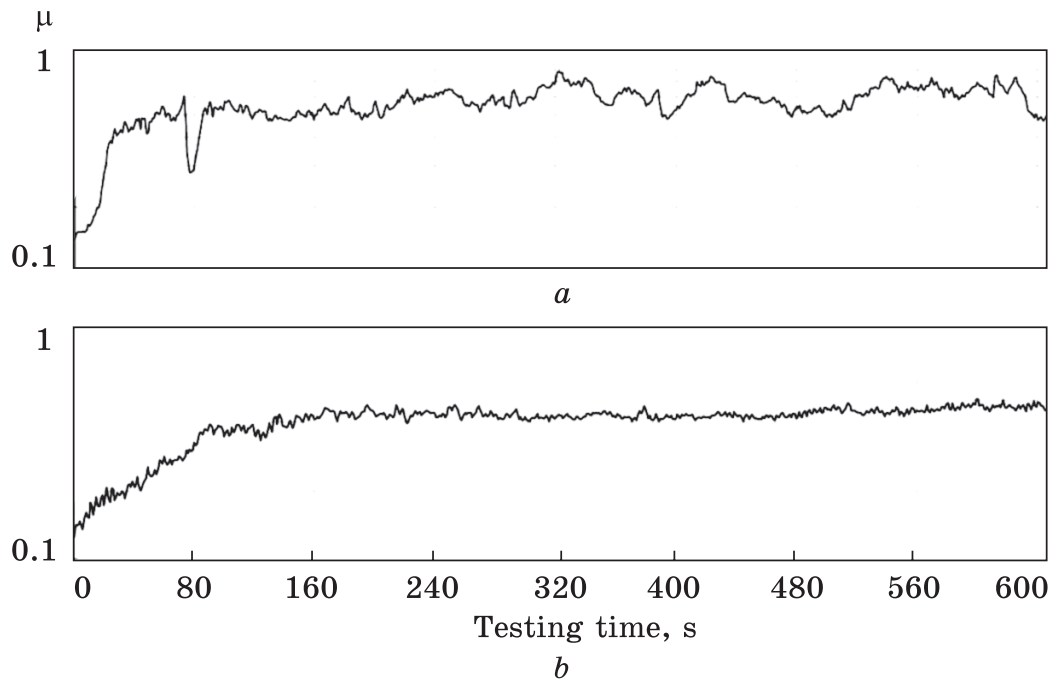

Fig. 10. Friction coefficient $\mu v s$. time of tribological tests on as-cast silumin $(a)$ and irradiated by intense pulse electron beam $\left(35 \mathrm{~J} / \mathrm{cm}^{2}, 150 \mu \mathrm{s}, 3\right.$ pulses $)(b)$

and nanocrystal surface layer, containing cells of high-speed crystallization separated by layers of the second phase.

Mechanical and tribological properties of the surface layer in silumin were measured using microhardness, friction coefficient, and wear parameter. The conditions of tests are given in Table 5. Obtained data (for these conditions) are represented in Table 6.

Analysing data in Table 6, we can assert that characteristics of the surface layer in silumin change significantly due to irradiation of the material by intense electron beam. For instance, friction coefficient drops by a factor of 1.3 , wear parameter (reciprocal value of wear resistance) decreases sevenfold, and microhardness increases by a factor of 1.7. Comparing results of tests with those obtained during studying structure of the irradiated layer, we can conclude as follows. A seven-

Table 6. The results of tribological and mechanical tests on silumin irradiated by intense pulse electron beam

\begin{tabular}{|c|c|c|c|}
\hline$E_{s}, \mathrm{~J} / \mathrm{cm}^{2}$ & Friction coefficient & $\begin{array}{c}\text { Wear parameter, } \\
10^{-3} \mathrm{~mm}^{3} / \mathrm{N} \cdot \mathrm{m}\end{array}$ & Microhardness, $H V$ \\
\hline 10 & 0.467 & 1.2 & 127 \\
15 & 0.495 & 1.5 & 142 \\
20 & 0.48 & 1.2 & 154 \\
25 & 0.48 & 0.7 & 157 \\
30 & 0.46 & 0.75 & 172 \\
35 & 0.42 & 0.74 & 163 \\
Initial & 0.559 & 4.9 & 103 \\
\hline
\end{tabular}



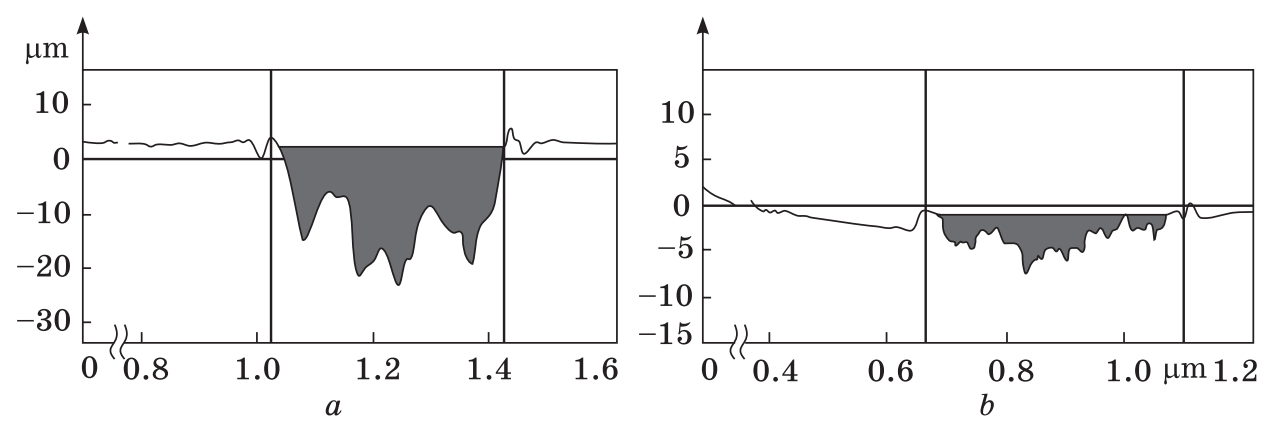

Fig. 11. The profiles of wear tracks in as-cast silumin $(a)$ and irradiated by intense

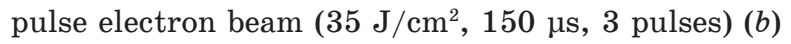

fold increase in wear resistance of silumin as compared with that in the initial state is observed on the samples, the surface layer of which has a submicro- and nanosize multiphase structure of cellular crystallization and does not contain primary inclusions of silicon and intermetallic compounds.

Figure 10 demonstrates varying friction coefficient of silumin during testing. Comparing the data of tests on silumin in as-cast (Fig. 10, a) and irradiated (Fig. 10, b) states, we can note as follows. Firstly, the time when friction coefficient changing becomes stationary is far longer in the irradiated sample. Secondly, the oscillation amplitude of friction coefficient is significantly higher for as-cast silumin.

Profiles of wear track in silumin (shown in Fig. 11) and numerical characteristics of the track (Table 7) also depend definitely on the state of the surface layer in the material. Wear tracks formed during tribological tests of as-cast material are significantly bigger and have a bigger difference in depth. Apparently, this is caused by big inclusions of silicon and intermetallic compounds in as-cast material, which chip during testing.

Multiple changes of mechanical and tribological characteristics in silumin are obviously caused by transformation of phase and element composition, and state of the defect substructure in the surface layer of silumin, which is initiated by high-speed thermal treatment taking place during electron beam treatment. Numerous studies $[14,15]$ reveal that irradiation of the material by concentrated energy fluxes (electron and

Table 7. Quantitative parameters of wear track in as-cast and irradiated silumin $\left(35 \mathrm{~J} / \mathrm{cm}^{2}, 150 \mu \mathrm{s}, 3\right.$ pulses $)$

\begin{tabular}{|c|c|c||c|c|c|}
\hline $\begin{array}{c}\text { Parameter } \\
\text { of a track }\end{array}$ & As-cast & $\begin{array}{c}\text { Irradiated } \\
\text { state }\end{array}$ & $\begin{array}{c}\text { Parameter } \\
\text { of a track }\end{array}$ & As-cast & $\begin{array}{c}\text { Irradiated } \\
\text { state }\end{array}$ \\
\hline Maximal depth, $\mu \mathrm{m}$ & 25.9 & 7.23 & Maximal height, $\mu \mathrm{m}$ & 1.06 & 0.117 \\
Area of a hole, $\mu \mathrm{m}^{2}$ & 6168 & 1265 & Area of crest, $\mu \mathrm{m}^{2}$ & 4.83 & 0.445 \\
\hline
\end{tabular}



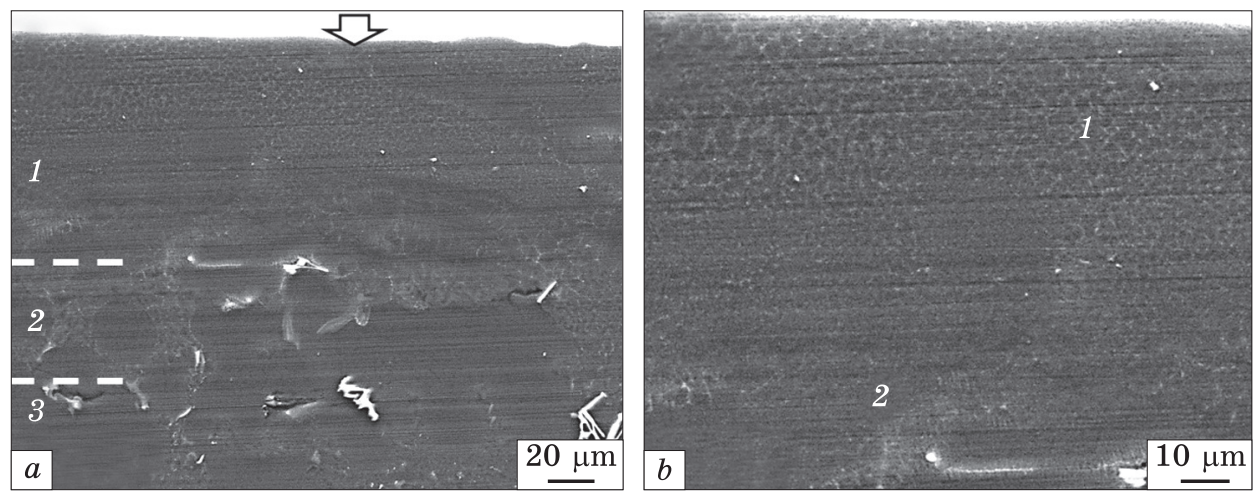

Fig. 12. Electron-microscopy image of the structure in cross section of silumin irradiated by intense pulse electron beam $\left(25 \mathrm{~J} / \mathrm{cm}^{2}, 150 \mu \mathrm{s}, 3\right.$ pulses $)$. Vertical arrow (in the left figure) indicates irradiated surface. Numbers indicate surface layer (1), intermediate layer (2), and layer of thermal effect (3)

ion beams, plasma fluxes, laser rays, etc.) results in formation of a graded structure. The graded structure (formed under irradiation of silumin by intense pulse electron beam) was studied during SEM-analysis of cross sections and TEM-analysis of the structure in the crosscut foils.

Using SEM, the cross sections of silumin were analysed. It was found out that thickness of the surface layer (where primary inclusions of silicon and intermetallic compounds are hardly detectable with the help of SEM) varies in the range from $35 \mu \mathrm{m}$ to $100 \mu \mathrm{m}$ and increases simultaneously with the growing energy density of electron beam (Fig. 12,a). Throughout this surface layer, there are uniformly distributed inclusions, the sizes of which vary in the range of 150-175 nm (Fig. 12,b). Taking into account a lighter contrast (as compared to the matrix) of these inclusions, we can conclude that they are saturated with atoms of alloying (impure) elements with higher atomic weight in comparison to aluminium, therefore, they are particles of an intermetallic phase.

The analysis of cross sections of silumin irradiated by electron beam revealed formation of a multilayer graded structure. According to morphology of the defect structure, three layers can be conventionally distinguished: surface layer (Fig. 12, $a$, layer 1), intermediate layer (Fig. 12, $a$, layer 2), and layer of thermal impact (Fig. 12, a, layer 3). The surface layer has a structure of cellular crystallization, formed during high-speed cooling of the material in the melted state (Fig. 12, b, layer 1). Primary inclusions of the second phase are not detected in this layer via the SEM-methods. The intermediate layer contains primary inclusions of the intermetallic phase, which are centres of crystallization for aluminium-based solid solution (Fig. 12, b, layer 2). 


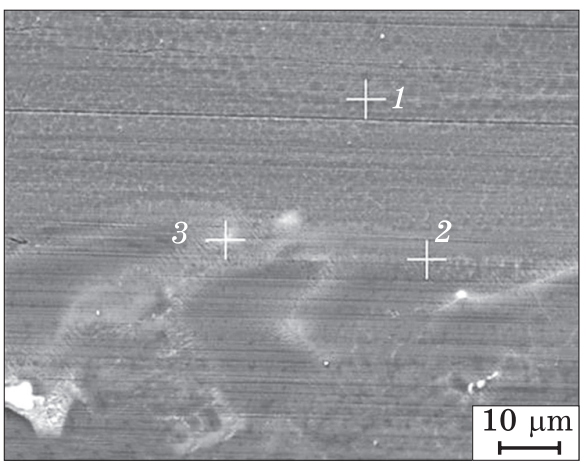

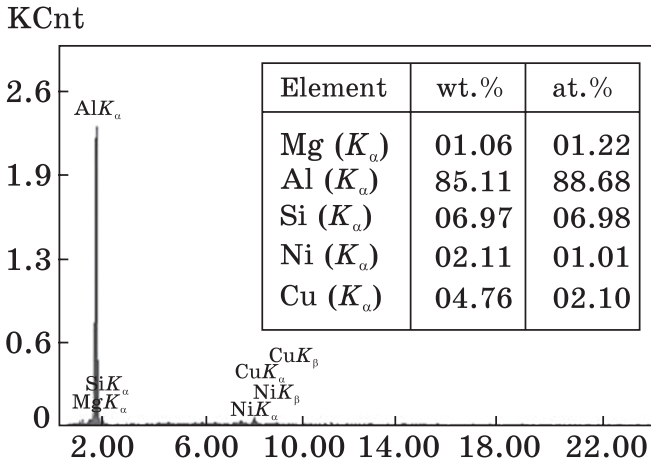

$b$

Fig. 13. Electron-microscopy image of the structure in as-cast silumin irradiated by electron beam ( $25 \mathrm{~J} / \mathrm{cm}^{2}, 150 \mu \mathrm{s}, 3$ pulses) $(a)$; energy spectra $(b)$ obtained on the surface area and shown in $(a)$. The table $(b)$ provides numerical results of the analysis on element composition in the area designated as 1 in $(a)$.

Figure 13 and Table 8 provide results of x-ray microstructural analysis of the surface and intermediate layers in the silumin samples.

Comparing results of the study of element composition in the surface layer (zone 1, Fig. 13, $a$ ) with results of element analysis presented in Fig. 2, $b$, we can note a rather low concentration of silicon and high concentration of nickel and copper as compared with cast silumin. Therefore, high-speed crystallization of silumin is associated with redistribution of alloying elements on the crystallization front, viz. displacement of silicon from the crystallizing layer. As mentioned above, the intermediate layer (Fig. 12) contains inclusions of not fully dissolved intermetallic phase (Fig. 13, a, zone 3) and is significantly silicon enrichment (Fig. 13, $a$, zone 2). Table 8 represents the quantitative results of $\mathrm{x}$-ray microspectral analysis of the silumin region shown in Fig. 13, $a$.

Table 8. The results of $\mathrm{x}$-ray microspectral analysis for thin section of silumin represented with the electron-microscopy image in Fig. 13

\begin{tabular}{|l|c|c|c|c|c|c|}
\hline \multirow{3}{*}{ Element } & \multicolumn{6}{|c|}{ Number of analysed part (Fig. 13, a) } \\
\cline { 2 - 7 } & \multicolumn{2}{|c|}{1} & \multicolumn{2}{|c|}{2} & \multicolumn{2}{c|}{3} \\
\cline { 2 - 7 } & wt. \% & at. $\%$ & wt. \% & at. \% & wt. \% & at. \% \\
\hline \multirow{2}{*}{$\mathrm{Mg}\left(K_{\alpha}\right)$} & 1.06 & 1.22 & 1.24 & 1.43 & 2.66 & 3.26 \\
$\mathrm{Al}\left(K_{\alpha}\right)$ & 85.11 & 88.68 & 76.42 & 79.09 & 72.51 & 80.0 \\
$\mathrm{Si}\left(K_{\alpha}\right)$ & 6.97 & 6.98 & 17.37 & 17.4 & 8.34 & 8.84 \\
$\mathrm{Fe}\left(K_{\alpha}\right)$ & 0.0 & 0.0 & 0.0 & 0.0 & 0.0 & 0.0 \\
$\mathrm{Ni}\left(K_{\alpha}\right)$ & 2.11 & 1.02 & 0.88 & 0.42 & 4.44 & 2.25 \\
$\mathrm{Cu}\left(K_{\alpha}\right)$ & 4.75 & 2.10 & 4.09 & 1.66 & 12.05 & 5.65 \\
\hline
\end{tabular}




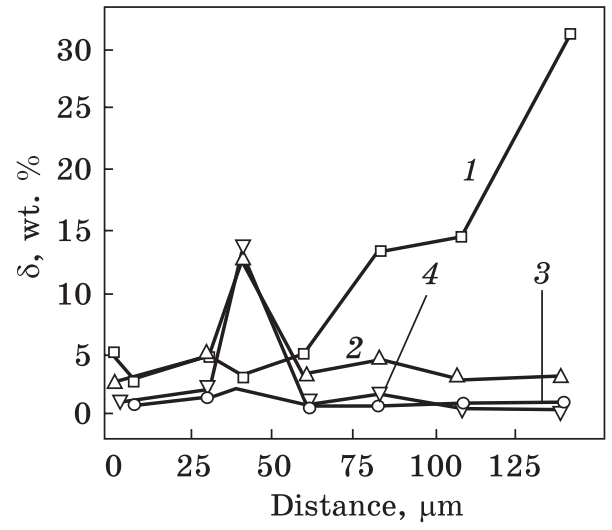

Fig. 14. The concentration of alloying elements in silumin $v s$. distance from the surface of irradiation by electron beam $\left(25 \mathrm{~J} / \mathrm{cm}^{2}, 150 \mu \mathrm{s}, 3\right.$ pulses), where $1-$ $\mathrm{Si}, 2-\mathrm{Cu}, 3-\mathrm{Mg}, 4-\mathrm{Ni}$

The results of $\mathrm{x}$-ray microspectral analysis of element composition in silumin, presented in Fig. 14, suggest as follows. First, the distribution of silicon in the surface layer with a thickness of $\approx 60$ $\mu \mathrm{m}$ is quasi-uniform; inclusions of silicon are detected far from the surface of irradiation. Second, the concentration of silicon atoms in the surface layer of $\approx 60 \mu \mathrm{m}$ is at least twice lower than declared in the Russian Standard GOST 30620-98. Third, inclusions of intermetallic phase are found at a depth of $\approx 40 \mu \mathrm{m}$ and even deeper.

Thus, using SEM methods, it was found out that as-cast silumin is a multiphase aggregate and contains inclusions of silicon and intermetallic compounds with rather different sizes and form. Irradiation of silumin samples by intense pulse electron beam is associated with melting of the surface layer, dissolution of silicon inclusions and intermetallic compounds, formation of a structure of cellular crystallization, and iterative release of submicro- and nanosize particles of the second phase. High-speed heating and crystallization of the melted layer are related to formation of a graded structure with regular distribution of silicon inclusions and intermetallic compounds.

A more precise measurement of the graded structure in the silumin layer surface modified by electron beam $\left(25 \mathrm{~J} / \mathrm{cm}^{2}, 150 \mu \mathrm{s}, 3\right.$ pulses $)$ and SEM of thin foils prepared from crosscut sections of samples treated by electron beam revealed formation of a cellular type structure (Fig. 15, a). The thickness of layer with the cellular crystallization structure is up to $40 \mu \mathrm{m}$. There were no inclusions typical for as-cast silumin detected in the layer with cellular structure. Using methods of x-ray microspectral analysis, it was found out that cells are formed by aluminium-based solid solution (Fig. 15, b). The cells are separated by thin layers of the second phase (Fig. 15, a). In compliance with the data of x-ray microspectral analysis, they are saturated with silicon and copper atoms (Fig. 15, $c$ and $d$ ). Table 9 provides quantitative results of the element analysis. We can clearly see that the main elements in the analysed surface section are aluminium, silicon, and copper; there is also a small amount of magnesium, nickel, iron, titanium, and manganese. It should be noted that the concentration of silicon in the surface layer is significantly lower than 

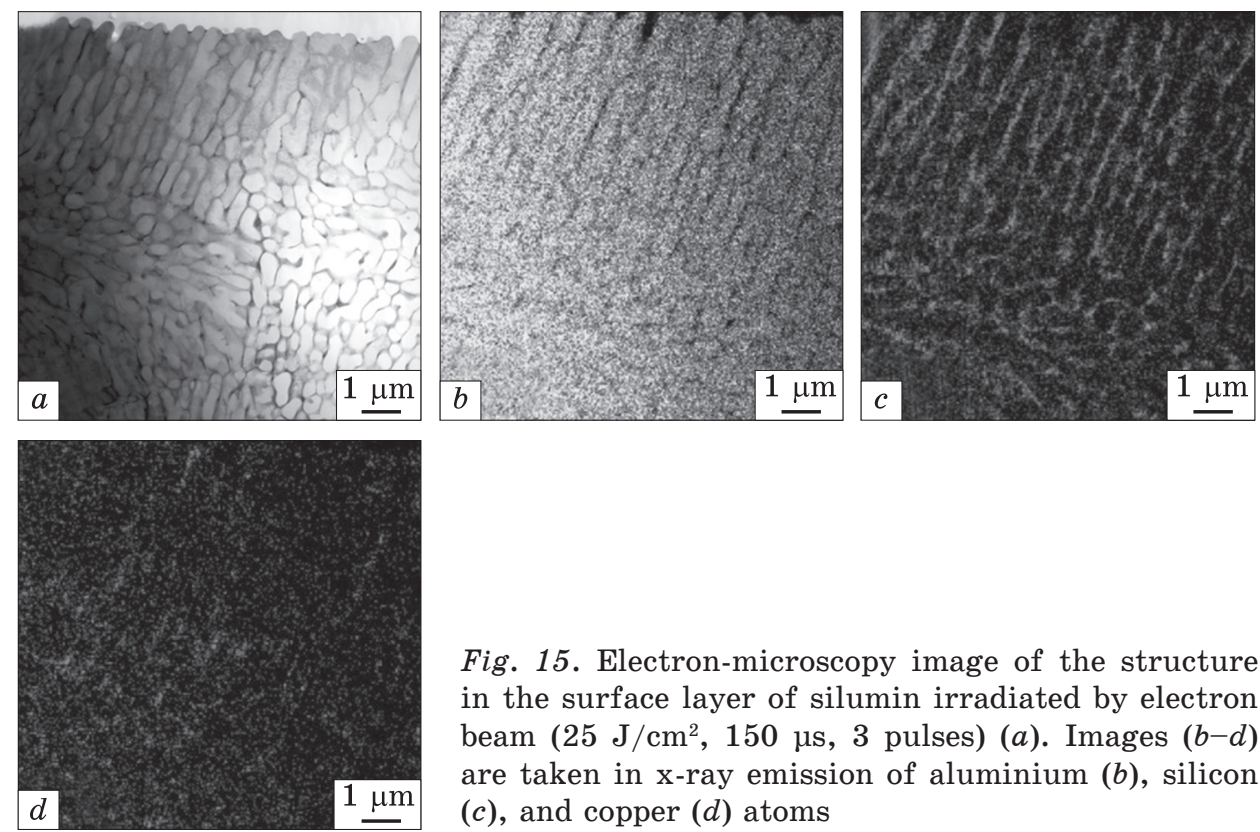

Fig. 15. Electron-microscopy image of the structure in the surface layer of silumin irradiated by electron beam $\left(25 \mathrm{~J} / \mathrm{cm}^{2}, 150 \mu \mathrm{s}, 3\right.$ pulses) $(a)$. Images $(b-d)$ are taken in x-ray emission of aluminium $(b)$, silicon $(c)$, and copper $(d)$ atoms

Table 9. The results of $\mathrm{x}$-ray microspectral analysis of the foil section represented in Fig. 15, $a$ (fitting coefficient: 0.2340)

\begin{tabular}{|l|c|r|r|r|r|r|r|}
\hline \multirow{2}{*}{ Thin } & \multirow{2}{*}{ Film } & \multirow{2}{*}{ Standardless } & & Standard & \multicolumn{2}{|c|}{ Quantitative } & Analysis \\
\cline { 4 - 7 } & & & $(\mathrm{keV})$ & mass.\% & \multicolumn{1}{|c|}{ counts } & error, \% & \multicolumn{1}{c|}{ at.\% } \\
\hline $\mathrm{Mg}$ & $K$ & & 1.253 & 1.11 & 5082.55 & 0.33 & 1.28 \\
$\mathrm{Al}$ & $K$ & & 1.486 & 86.60 & 402539.09 & 0.00 & 89.82 \\
$\mathrm{Si}$ & $K$ & & 1.739 & 6.16 & 29748.77 & 0.07 & 6.13 \\
$\mathrm{Ti}$ & $K$ & & 4.508 & 0.13 & 470.44 & 4.05 & 0.08 \\
$\mathrm{Mn}$ & $K$ & & 5.894 & 0.04 & 131.09 & 16.84 & 0.02 \\
$\mathrm{Fe}$ & $K$ & & 6.398 & 0.29 & 875.37 & 2.31 & 0.14 \\
$\mathrm{Ni}$ & $K$ & & 7.471 & 0.76 & 2060.27 & 1.08 & 0.36 \\
$\mathrm{Cu}$ & $K$ & & 8.040 & 4.92 & 11762.94 & 0.20 & 2.17 \\
\hline Total & & & 100.00 & & & 100.00 \\
\hline
\end{tabular}

that regulated in the Russian Standard GOST for silumin. Similar results were obtained by methods of SEM and x-ray phase analysis.

The average size of the cells of high-speed crystallization in the surface layer is $0.4 \pm 0.11 \mu \mathrm{m}$. The size distribution of cells is monomodal, indicating high size uniformity in the formed structure (Fig. 16). As deeper from the surface of irradiation, the increase in average sizes of crystallization cells is revealed; on the bottom edge of the layer with cellular crystallization they are of $0.65 \pm 0.22 \mu \mathrm{m}$. 


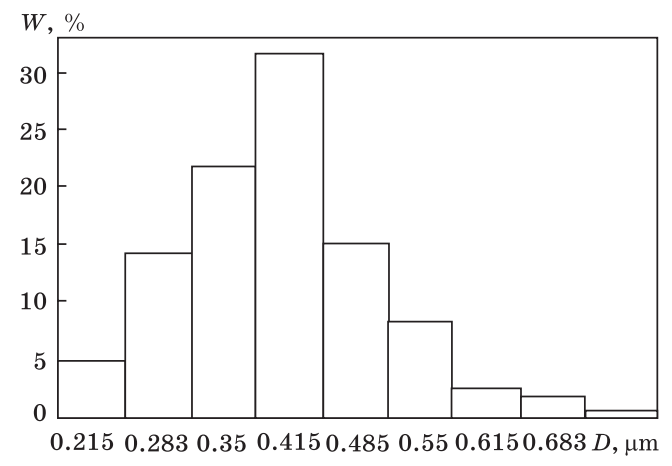

Fig. 16. The size distribution of highspeed crystallization cells in the surface layer of silumin irradiated by electron beam $\left(25 \mathrm{~J} / \mathrm{cm}^{2}, 150 \mu \mathrm{s}, 3\right.$ pulses)

The surface layer of silumin with the structure of cellular crystallization contains grains of lamellar eutectic (Fig. 17). First grains of eutectic are found in the layer at a depth of $\approx 15 \mu \mathrm{m}$. A relative concentration of grains increases as deeper from the surface of irradiation. The grains of eutectic are located like islands or layers between cells of high-speed crystallization of aluminium. The grains of eutectic indicate local regions in the surface layer of the material with a quite higher $(\approx 12$ at. $\%)$ concentration of silicon atoms. The sizes of eutectic grains are similar to those of aluminium-based solid solution (cells of crystallization). The cross sizes of eutectic plates vary from $25 \mathrm{~nm}$ to $50 \mathrm{~nm}$.

Figure 18 shows revealed layer of silumin at a depth of $50-70 \mu \mathrm{m}$, where aluminium and silicon melt and inclusions of intermetallic compounds (with casting origin) remain. In this case, the structure of cellular crystallization of aluminium and grains of lamellar eutectic are formed. The inclusions of intermetallic compounds are as centres of cellular crystallization.

The layer of silumin, where only aluminium melts and primary inclusions of silicon and intermetallic compounds are detected, precipitates at a distance of $80-90 \mu \mathrm{m}$ from the surface of irradiation. In this
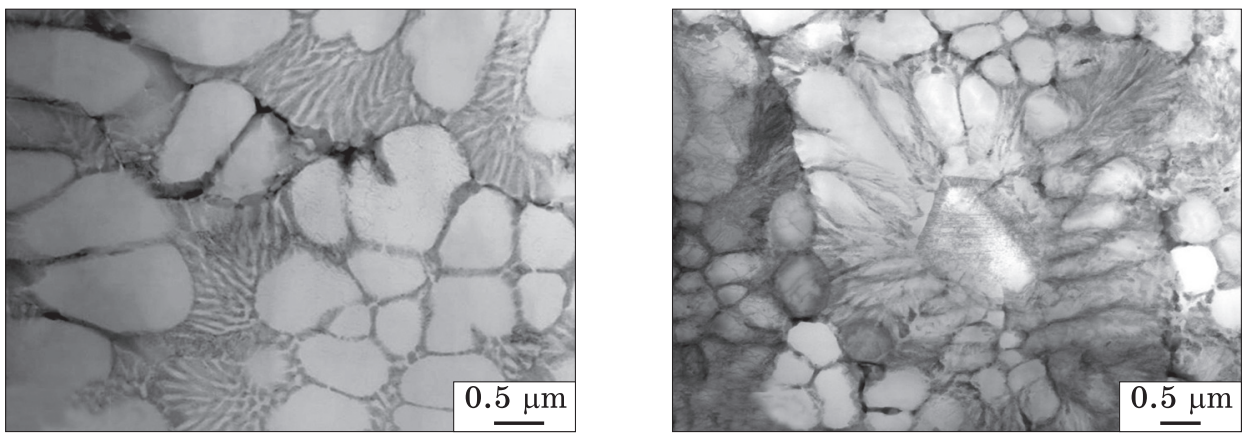

Fig. 17. The structure of silumin layer (at a depth of $\approx 30 \mu \mathrm{m}$ ) after electron beam exposure $\left(25 \mathrm{~J} / \mathrm{cm}^{2}, 150 \mu \mathrm{s}, 3\right.$ pulses $)$

Fig. 18. The structure of silumin layer (at a depth of $\approx 50 \mu \mathrm{m}$ ) after electron beam exposure $\left(25 \mathrm{~J} / \mathrm{cm}^{2}, 150 \mu \mathrm{s}, 3\right.$ pulses $)$ 

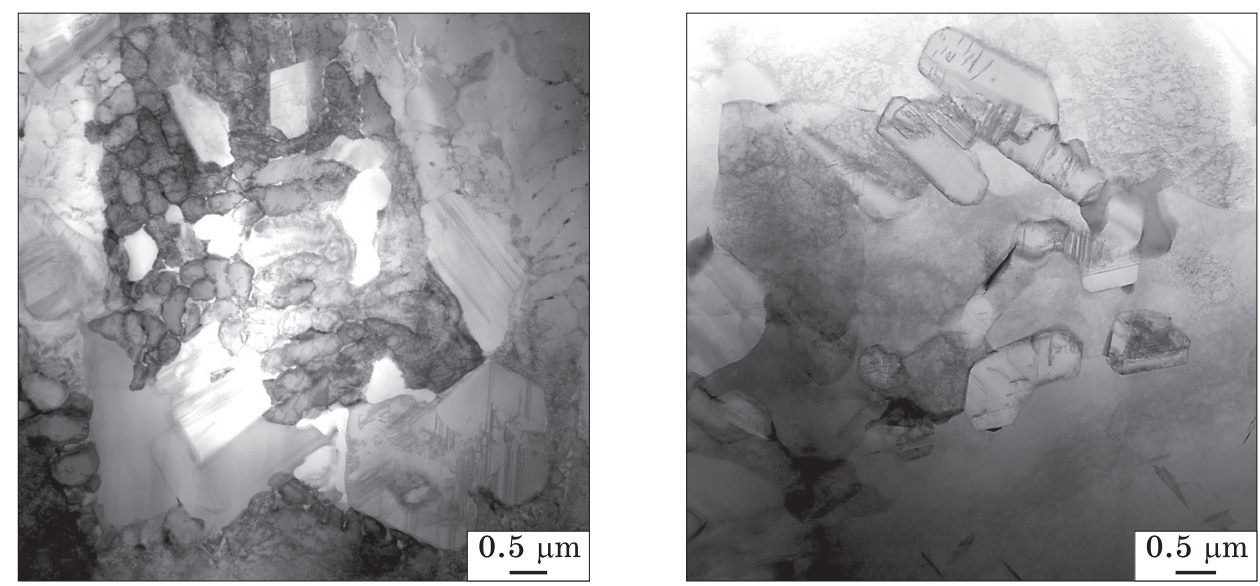

Fig. 19. The structure of silumin layer (at a depth of $\approx 90 \mu \mathrm{m}$ ) after electron beam treatment $\left(25 \mathrm{~J} / \mathrm{cm}^{2}, 150 \mu \mathrm{s}, 3\right.$ pulses)

Fig. 20. The structure of silumin layer (at a depth $\approx 120 \mu \mathrm{m}$ ) after electron beam treatment ( $25 \mathrm{~J} / \mathrm{cm}^{2}, 150 \mu \mathrm{m}, 3$ pulses)

case, in the structure there are cells of high-speed crystallization of aluminium. Submicron grains of lamellar eutectic are not found (Fig. 19). As deeper from the surface of irradiation (100 $\mu \mathrm{m}$ and more), the structural region of the thermal impact is revealed by intense pulse electron beam $\left(25 \mathrm{~J} / \mathrm{cm}^{2}, 150 \mu \mathrm{s}, 3\right.$ pulses $)$. This structural region is similar to the structure of silumin in the initial state according to element and phase composition. Figures 20 and 21 demonstrate typical structure in this layer of silumin.

Using methods of x-ray microspectral analysis of thin foils, it was revealed that element composition of silumin irradiated by electron beam depends regularly on the distance from the surface of irradiation (Table 10). The analysis of data in Table 10 suggests that silicon concentration changes most significantly, a relative concentration of this element grows from 6.2 wt. $\%$ in the surface layer to $10.4 \mathrm{wt} . \%$ in the layer at a depth of $30 \mu \mathrm{m}$. Therefore, melting of silumin by intense pulse electron beam $\left(25 \mathrm{~J} / \mathrm{cm}^{2}\right.$,

Fig. 21. The structure of silumin layer (at a depth of $\approx 200 \mu \mathrm{m}$ ) after electron beam treatment $\left(25 \mathrm{~J} / \mathrm{cm}^{2}, 150 \mu \mathrm{s}, 3 \mathrm{pul}-\right.$ ses)

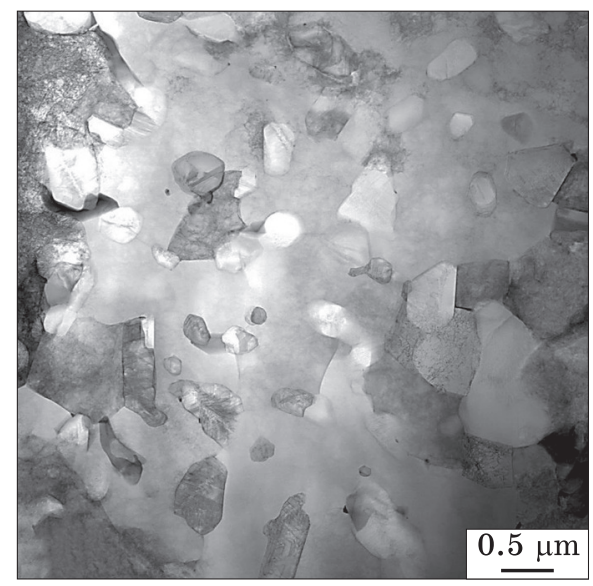



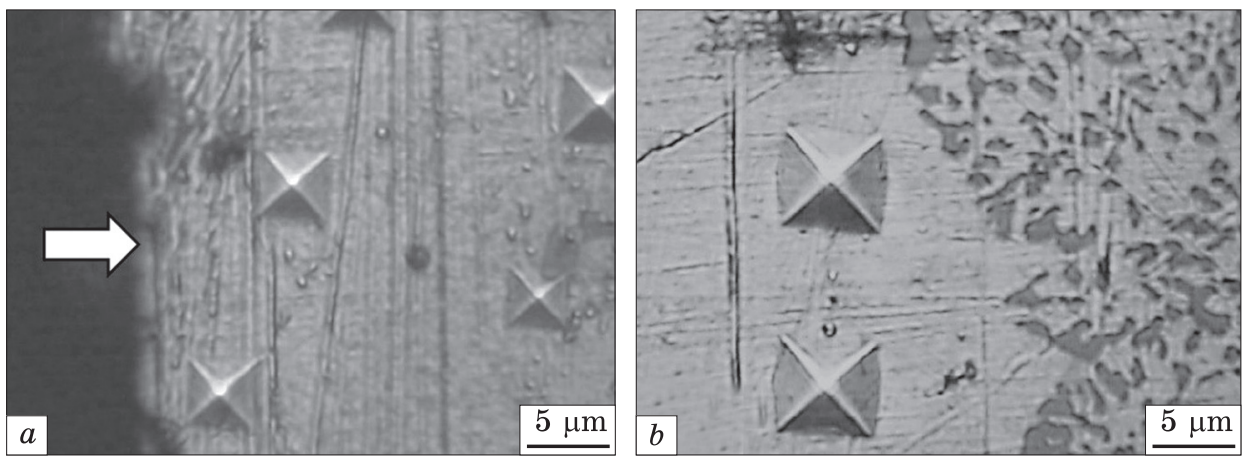

Fig. 22. The structure of the cross section of silumin sample (with indenter impression) irradiated by intense pulse electron beam $\left(25 \mathrm{~J} / \mathrm{cm}^{2}, 150 \mu \mathrm{s}, 3\right.$ pulses $): a-$ the structure of silumin near the irradiated surface, $b$ - at a distance of $200 \mu \mathrm{m}$ from the surface. The arrow (in the left figure) indicates the surface of irradiation

$150 \mu \mathrm{s}, 3$ pulses) is associated with the drop in silicon concentration in the surface layer, the thickness of which is up to $30 \mu \mathrm{m}$.

We can suggest that the decrease in concentration of alloying elements in the surface layer of silumin irradiated by intense pulse electron beam, can contribute to the loss in strength of the surface layer. Hardness of the modified layer was determined on the crosscut polished thin sections at a load on indenter of $30 \mathrm{mN}$. Figure 22 shows face of metallographic thin sections with indenter imprints.

One can clearly see that the sizes of imprints and, therefore, the hardness depend substantially on the distance to the surface of irradiation (the surface of irradiation is indicated by the arrow in Fig. 22, $a$ ). The sizes of indenter imprints close to the surface of irradiation (Fig. 2, a) are quite smaller than those located deeper $(200 \mu \mathrm{m}$, Fig. $22, b)$ from the surface of irradiation. That is why the irradiation of silumin by electron beam is associated with hardening of the surface layer in a sample, despite the lowering of alloying degree.

Figure 23 provides results of plotting hardness profile of the irradiated samples of silumin. The analysis of the results (Fig. 23) suggests

Table 10. The element composition of silumin irradiated by intense pulse electron beam $\left(25 \mathrm{~J} / \mathrm{cm}^{2}, 150 \mu \mathrm{s}, 3\right.$ pulses $)$

\begin{tabular}{|c|c|c|c|c||c|c|c|c|c|}
\hline \multirow{2}{*}{$\begin{array}{c}\text { Element, } \\
\text { wt. } \%\end{array}$} & \multicolumn{3}{|c|}{$\begin{array}{c}\text { Distance between analysed layer } \\
\text { and irradiation surface, } \mu \mathrm{m}\end{array}$} & \multirow{2}{*}{$\begin{array}{c}\text { Element, } \\
\text { wt.\% }\end{array}$} & \multicolumn{3}{|c|}{$\begin{array}{r}\text { Distance between analysed layer } \\
\text { and irradiation surface, } \mu \mathrm{mm}\end{array}$} \\
\cline { 2 - 4 } & 3 & 8 & 15 & 30 & & 3 & 8 & 15 & 30 \\
\hline $\mathrm{Mg}$ & 1.11 & 0.71 & 0.28 & 0.38 & $\mathrm{Mn}$ & 0.04 & 0.03 & 0.05 & 0.05 \\
$\mathrm{Al}$ & 86.60 & 86.09 & 87.2 & 83.95 & $\mathrm{Fe}$ & 0.29 & 0.48 & 0.22 & 0.24 \\
$\mathrm{Si}$ & 6.16 & 6.9 & 7.2 & 10.42 & $\mathrm{Ni}$ & 0.76 & 1.26 & 0.42 & 0.58 \\
$\mathrm{Ti}$ & 0.13 & 0.23 & 0.18 & 0.2 & $\mathrm{Cu}$ & 4.92 & 4.32 & 4.43 & 4.18 \\
\hline
\end{tabular}



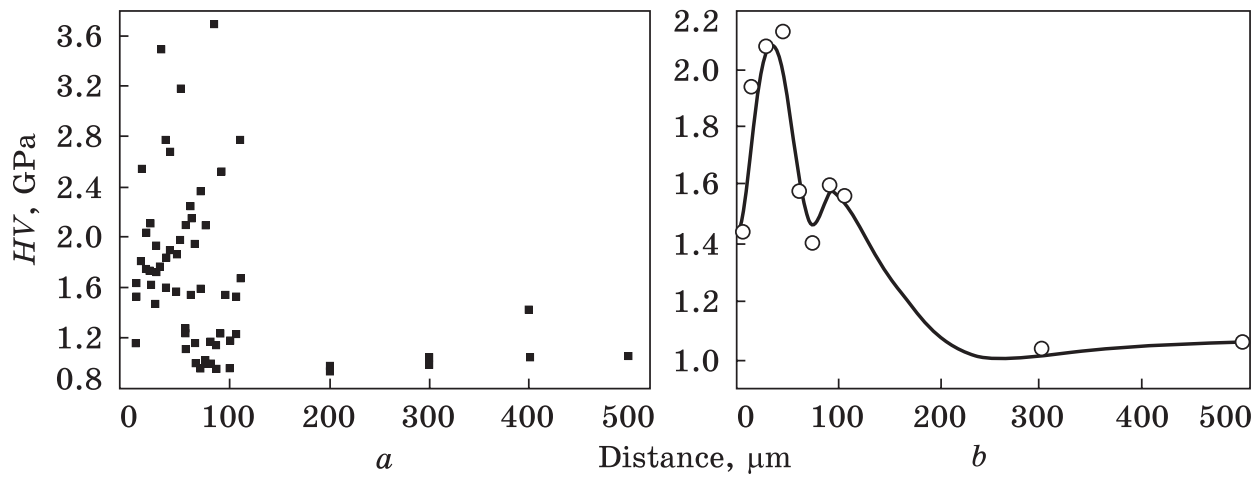

Fig. 23. The values of hardness $(a)$ determined under nanoindentation of the cross section in silumin irradiated by intense pulse electron beam $\left(25 \mathrm{~J} / \mathrm{cm}^{2}, 150 \mu \mathrm{s}\right.$, 3 pulses), where averaged hardness values $v s$. distance from the surface of irradiation are represented in $(b)$

that silumin hardness changes nonmonotonously, reaching its maximums in the layer at a depth of 30-50 $\mu \mathrm{m}$. Silumin hardness exceeds hardness in the initial state by a factor of 3.8-4.2. In the layer adjacent to the surface of irradiation (i.e., located at a depth of $\approx 5 \mu \mathrm{m}$ ), the hardness is higher than that of as-cast silumin (in our case, it is a layer at a depth of $500 \mu \mathrm{m}$ ) by a factor of $\approx 1.6$.

Therefore, the results of SEM allow suggesting that the increase of silumin hardness (by a factor of 3.8-4.2 in the layer at a depth of $\approx 30 \mu \mathrm{m}$ ) is caused by formation of a morphologically two-base structure. This structure contains submicron cells of high-speed crystallization of aluminiumbased solid solution with nanosize layers of the second phase located on the cell boundaries, and submicron cells of eutectic silumin crystallization.

\section{Conclusions}

Using methods of scanning electron microscopy, it was found out that as-cast hypoeutectic silumin is a multiphase aggregate, which is formed by grains of aluminium-based solid solution, grains of eutectic, inclusions of silicon and intermetallic compounds with a wide range of sizes and different shapes; furthermore, the distribution of alloying elements is significantly inhomogeneous. It is reported that irradiation of silumin by intense pulse electron beam $\left(20-35 \mathrm{~J} / \mathrm{cm}^{2}, 150 \mu \mathrm{s}, 3\right.$ pulses, $\left.0.31 / \mathrm{c}\right)$ is associated with melting of the surface layer, dissolution of silicon inclusions and intermetallic compounds, formation of the structure of cellular crystallization, and iterative release of submicro- and nanosize particles of the second phase. A considerable drop (1.5-2 times) of silicon concentration is detected in the layer adjacent to the surface of irradiation. It is identified that the concentration of silicon grows as far 
from the surface of irradiation and reaches referential values in the layer at a depth of $\approx 30 \mu \mathrm{m}$.

A multiple alteration of mechanical and tribological characteristics is revealed in the surface layer of silumin irradiated by intense pulse electron beam. Friction coefficient decreases by a factor of 1.3 , wear parameter (reverse value of wear resistance) decreases by a factor of 7 , while microhardness increases by a factor of 1.7. It is assumed that the sevenfold increase in wear resistance in the modified layer of silumin as compared with as-cast material is caused by submicro- and nanosize multiphase structure of cellular crystallization without primary inclusions of silicon and intermetallic compounds.

It is determined that high-speed mode of melting and subsequent crystallization, which take place during intense pulse electron beam irradiation, result in formation of silumin with the graded structure in the surface layer. The average size of cells is $0.4 \pm 0.11 \mu \mathrm{m}$ at the surface of irradiation and $0.65 \pm 0.22 \mu \mathrm{m}$ on the lower edge of the cellular crystallized layer. The volume of cells is formed by aluminium-based solid solution. The cells are separated by thin layers of the second phase saturated with atoms of silicon and copper. In the layer deeper than 15 $\mu \mathrm{m}$, the formation of submicron grains of lamellar eutectic is detected. The cross sizes of eutectic plates vary from $25 \mathrm{~nm}$ to $50 \mathrm{~nm}$. At a depth of 50-70 $\mu \mathrm{m}$, there is a layer of silumin, where melting of aluminium and silicon takes place, and inclusion of intermetallic compounds remain. High-speed crystallization in this layer is associated with formation of the structure with cellular crystallization of aluminium and grains of lamellar eutectic. At a depth of $80-90 \mu \mathrm{m}$, there is a layer of silumin detected, where aluminium melts, while inclusions of as-cast originated silicon and intermetallic compounds remain. In this case, cells of high-speed crystallization of aluminium are found in the structure. The submicron grains of lamellar eutectic are not detected.

It is demonstrated that hardness of irradiated silumin varies non-monotonously, reaching maximum value in the layer at a depth of 30-50 $\mu \mathrm{m}$. This maximum exceeds hardness of the material in the initial state by a factor of 3.8-4.2. In the layer close to the irradiated surface (i.e. at a depth of $\approx 5 \mu \mathrm{m}$ ), the hardness is $\mathbf{1 . 6}$ times higher than that for as-cast material. It is determined that the increase of hardness in the surface layer by a factor of $\approx 1.6$ is caused by formation of the submicron structure with cellular crystallization, nanosize layers of the second phase located on the cell boundaries. The increase by a factor of 3.8-4.2 in hardness of the subsurface layer in silumin is related to morphologically two-base structure, which contains sub-micron cells of high-speed crystallization of aluminium-based solid solution and nanosize layers of the second phase on the boundaries of the cells, and sub-micron cells of eutectic crystallization of silumin. 
Acknowledgments. The work is carried out under partial financial support of a grant provided by Russian Foundation for Basic Research (project No. 16-43-700659) and financial support of Ministry of Science and Education of Russian Federation within the framework of Government Order No. 3.1283.2017/4.6.

\section{REFERENCES}

1. L.F. Mondolfo, Aluminium Alloys: Structure and Properties (London: ButterworthHeinemann: 1976).

2. N.A. Belov, Fazovyy Sostav Promyshlennykh i Perspektivnykh Alyuminievykh Splavov [Phase Composition of Industrial and Prospective Aluminium Alloys] (Moscow: MISiS: 2010) (in Russian).

3. A.V. Kurdyumov, Proizvodstvo Otlivok iz Splavov Tsvetnykh Metallov: Uchebnik dlya VUZov [Manufacturing of Casts from Nonferrous Metal Alloys: Textbook for Higher Educational Institutions] (Moscow: Metallurgiya: 1986) (in Russian).

4. V.E. Gromov, K.V. Aksyonova, S.V. Konovalov, and Yu.F. Ivanov, Usp. Fiz. Met., 16, No. 4: 265 (2015) (in Russian).

5. V.E. Gromov, K.V. Sosnin, Yu.F. Ivanov, and O.A. Semina, Usp. Fiz. Met., 16, No. 3: 175 (2015) (in Russian).

6. M.M. Makhloufe and H.V. Guthy, J. Light Metals, 1, No. 4: 199 (2001).

7. V. Paramo, R. Colas, E. Velasco, and S. Valtierra, J. Mater. Engineer. Perform., 9, No. 6: 616 (2000).

8. I.F. Kolobnev, V.V. Krymov, and A.V. Melnikov, Spravochnik Liteyshchika. Tsvetnoe Litye iz Legkikh Splavov [Reference Book for a Caster. Nonferrous Casting of Light Alloys] (2 $2^{\text {nd }}$ edition) (Moscow: Mashinostroenie: 1974) (in Russian).

9. S.M. Petrov, Povyshenie Kachestva Vtorichnykh Liteinykh Alyuminievykh Splavov [Quality Improvement of the Secondary Casting Aluminium Alloys] (Leningrad: LDNTP: 1988) (in Russian).

10. V.V. Uglov, Strukturno-Fazovyye Prevrashcheniya v Alyuminii, Zheleze i Ego Splavakh pri Kombinirovannykh Ionnykh i Plazmennykh Vozdeistviyakh [StructurePhase Transformations in Aluminium, Iron and Its Alloys under Combined Iion and Plasma Influence] (Thesis of Disser. for Dr. Phys.-Math. Sci.) (Minsk: Belarus State University: 2006) (in Russian).

11. V.L. Yakushin, Russian Metallurgy (Metally), 2005, No. 2: 104 (2005).

12. E.A. Petrikova, A.P. Laskovnev, and Yu. F. Ivanov, Modifikatsiya Struktury $i$ Svoistv Ehvtekticheskogo Silumina Ehlektronno-Ionno-Plazmennoy Obrabotkoy [Modification of Structure and Properties of Eutectic Silumin by Electron-IonPlasma Treatment] (Minsk: Navuka: 2013) (in Russian).

13. V. Rotshtein, Yu. Ivanov, and A. Markov, Materials Surface Processing by Directed Energy Techniques (Ed. Y. Pauleau) (Amsterdam: Elsevier Science: 2006), Ch. 6, pp. 205-240.

14. Ehvolutsiya Struktury Poverkhnostnogo Sloya Stali, Podvergnutoy EhlektronnoIonno-Plazmennym Metodam Obrabotki [Evolution of Structure in the Surface Layer of Steel Processed by Electron-Ion-Plasma Method of Treatment] (Eds. N.N. Koval and Yu.F. Ivanov) (Tomsk: Publishing House of NTL: 2016) (in Russian).

15. Yu.F. Ivanov, E.A. Petrikova, A.D. Teresov, and P. Moskvin, Adv. Mater. Res., 872: 157 (2014). 
16. Y. Hao, B. Gao, G.F. Tu, H. Cao, S.Z. Hao, and C. Dong, Appl. Surf. Sci., 258, No. 6: 2052 (2012).

17. B. Gao, S.Z. Hao, J.X. Zou, L.M. Jiang, J.Y. Zhou, and C. Dong, Trans. Mater. Heat Treatment, No. 5: 1029 (2004).

18. B. Gao, Y. Hao, W.F . Zhuang, G.F. Tu, W.X. Shi, S.W. Li, S.Z. Hao, C. Dong, and M.C. Li, Phys. Proc., 18: 187 (2011).

19. Y. Hao, B. Gao, G.F. Tu, S.W. Li, and C. Dong, Nucl. Instrum. Methods Phys. Res. B, 269, No. 13: 1499 (2011).

20. Y. Hao, B. Gao, G.F. Tu, S.W. Li, S.Z. Hao, and C. Dong, Appl. Surf. Sci., 257, No. 9: 3913 (2011).

21. Y. Hao, B. Gao, G.F. Tu, S.W. Li, S.Z. Hao, and C. Dong, Trans. Mater. Heat Treatment, No. 9: 115 (2010).

22. Y. Hao, B. Gao, G.F. Tu, Z. Wang, and C.Z. Hao, Mater. Sci. Forum., 675-677: 693 (2011).

23. J. An, X.X. Shen, Y. Lu, Y.B. Liu, R.G. Li, C.M. Chen, and M.J. Zhang, Surf. Coat. Technol., 200, Nos. 18-19: 5590 (2006).

24. J. An, X.X. Shen, and Y. Lu, Wear, 261, No. 2: 208 (2006).

25. S. Hao, S. Yao, J. Guan, A. Wu, P. Zhong, and C. Dong, Curr. Appl. Phys., 1, Nos. 2-3: 203 (2001).

26. T. Grosdidier, J.X. Zou, N. Stein, C. Boulanger, S.Z. Hao, and C. Dong, Scripta Materialia, 58, No. 12: 1058 (2008).

27. Yu.F. Ivanov, Struktura i Svoistva Perspektivnykh Metallicheskikh Materialov [Structure and Properties of Prospective Metallic Materials] (Ed. A. I. Potekaev) (Tomsk: Publishing House of NTL: 2007) (in Russian).

28. A.P. Babichev, Fizicheskie Velichiny: Spravochnik [Physical Values: Handbook] (Eds. I. S. Grigoriev, E. S. Meilikhov) (Moscow: Energoatomizdat: 1991) (in Russian).

Received June 13, 2018; in final version, June 27, 2018

Ю.Ф. Іванов ${ }^{1,2}$, В.С. Гролов ${ }^{3}$, С.В. Коновалов ${ }^{4}$,

Д.В. Загуляєв ${ }^{3}$, С.А. Петрікова ${ }^{1}$, А.П. Семін ${ }^{1}$

${ }^{1}$ Інститут сильнострумової електроніки СВ РАН, просп. Академічний, 2/3; 634055 Томськ, Росія

${ }^{2}$ Національний дослідницький Томський політехнічний університет, просп. Леніна, 30; 634050 Томськ, Росія

${ }^{3}$ Сибірський державний індустріальний університет, вул. Кірова, 42; 654007 Новокузнецьк, Росія

${ }^{4}$ Самарський національний дослідницький університет

імені академіка С. П. Корольова,

Московське шосе, 34; 443086 Самара, Росія

МОДИФІКАЦІЯ СТРУКТУРИ ТА ВЛАСТИВОСТЕЙ

ПОВЕРХНІ ДОЕВТЕКТИЧНОГО СИЛУМІНУ ІНТЕНСИВНИМИ

ІМПУЛЬСНИМИ ЕЛЕКТРОННИМИ ПУЧКАМИ

Методами сучасного фізичного матеріялознавства виконано аналізу структурнофазових станів, трибологічних і механічних властивостей доевтектичного силуміну, що піддається електронно-пучковому обробленню (ЕПО) за наступних па-

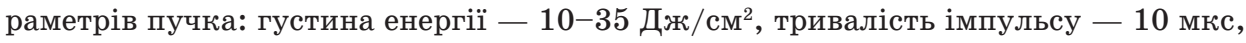
кількість імпульсів - 3, частота проходження - 0,3 Гц. У початковому стані 
структуру силуміну сформовано зернами твердого розчину на основі алюмінію, зернами евтектики, включеннями кремнію й інтерметалідів різної форми та розмірів. ЕПО з густиною енергії у 20-35 Дж/ $\mathrm{cm}^{2}$ приводить до топлення поверхневого шару, розчинення включень кремнію й інтерметалідів, формування структури високошвидкісної коміркової кристалізації, повторного виділення частинок другої фази субмікронанорозмірного діяпазону. Середній розмір осередків кристалізації - 0,3-0,5 мкм у поверхні опромінення та $0,4-0,8$ мкм на нижній межі шару з комірчастою структурою. Виконано аналізу градієнтних структурнофазових станів на глибині до 120 мкм. В шарі, розташованому на глибині понад 15 мкм, виявлено формування субмікронних зерен пластинчастої евтектики. Поперечні розміри пластин евтектики змінюються в межах від 25 нм до 50 нм. Показано, що нанотвердість опроміненого силуміну змінюється немонотонним чином, сягаючи максимального значення, що перевищує твердість вихідного стану в $\approx 4$ рази на глибині $\approx 30$ мкм. В шарі, прилеглому до поверхні опромінення (тобто розташованому на глибині $\approx 5$ мкм), величина твердости перевищує твердість литого силуміну в $\approx 1,6$ рази. Надано фізичну інтерпретацію спостережуваних змін структури та властивостей при опроміненні.

Ключові слова: доевтектичний силумін, електронні пучки, комірки високошвидкісної кристалізації, евтектика, інтерметаліди, нанотвердість.

Ю.Ф. Иванов ${ }^{1,2}$, В.Е. Гролов ${ }^{3}$, С.В. Коновалов ${ }^{4}$,

Д.В. Загуляев ${ }^{3}$, Е.А. Петрикова ${ }^{1}$, А.П. Семин ${ }^{1}$

${ }^{1}$ Институт сильноточной электроники СО РАН, просп. Академический, 2/3; 634055 Томск, Россия

${ }^{2}$ Национальный исследовательский Томский политехнический университет, просп. Ленина, 30; 634050 Томск, Россия

${ }^{3}$ Сибирский государственный индустриальный университет, ул. Кирова, 42; 654007 Новокузнецк, Россия

${ }^{4}$ Самарский национальный исследовательский университет имени академика С. П. Королева, Московское шоссе, 34; 443086 Самара, Россия

\section{МОДИФИКАЦИЯ СТРУКТУРЫ И СВОЙСТВ ПОВЕРХНОСТИ ДОЭВТЕКТИЧЕСКОГО СИЛУМИНА ИНТЕНСИВНЫМИ ИМПУЛЬСНЫМИ ЭЛЕКТРОННЫМИ ПУЧКАМИ}

Методами современного физического материаловедения выполнен анализ структурно-фазовых состояний, трибологических и механических свойств доэвтектического силумина, подвергнутого электронно-пучковой обработке (ЭПО) со сле-

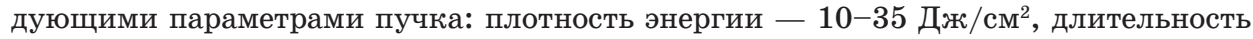
импульса -10 мкс, количество импульсов -3 , частота следования $-0,3$ Гц. В исходном состоянии структура силумина сформирована зёрнами твёрдого раствора на основе алюминия, зёрнами эвтектики, включениями кремния и интерме-

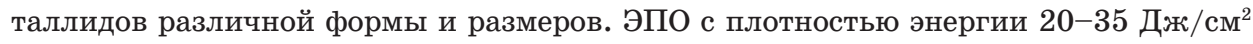
приводит к плавлению поверхностного слоя, растворению включений кремния и интерметаллидов, формированию структуры высокоскоростной ячеистой кристаллизации, повторному выделению частиц второй фазы субмикронаноразмерного диапазона. Средний размер ячеек кристаллизации - 0,3-0,5 мкм у поверхности облучения и $0,4-0,8$ мкм на нижней границе слоя с ячеистой структурой. Выполнен анализ градиентных структурно-фазовых состояний на глубине до 
120 мкм. В слое, расположенном на глубине более 15 мкм, выявлено формирование субмикронных зёрен пластинчатой эвтектики. Поперечные размеры пластин эвтектики изменяются в пределах от 25 нм до 50 нм. Показано, что нанотвёрдость облучённого силумина изменяется немонотонным образом, достигая максимального значения, превышающего твёрдость исходного состояния в $\approx 4$ раза на глубине $\approx 30$ мкм. В слое, прилегающем к поверхности облучения (то есть расположенном на глубине $\approx 5$ мкм), величина твёрдости превышает твёрдость литого силумина в $\approx 1,6$ раза. Дана физическая интерпретация наблюдаемых изменений структуры и свойств при облучении.

Ключевые слова: доэвтектический силумин, электронные пучки, ячейки высокоскоростной кристаллизации, эвтектика, интерметаллиды, нанотвёрдость. 